\title{
Material fluxes through the procaryotic compartment in a eutrophic backwater branch of the River Danube
}

\author{
A. K. T. Kirschner, T. Ulbricht, A. Steitz, B. Velimirov* \\ Institut für Medizinische Biologie, Arbeitsgruppe Allgemeine Mikrobiologie, Universität Wien, Währingerstr. 10, \\ A-1090 Wien, Austria
}

\begin{abstract}
A seasonal study on the quantification of energy fluxes through the microbial compartment and on bacterial morphotype succession was performed in a hypertrophic shallow backwater branch, which had shifted from a macrophyte-dominated clear-water to a phytoplankton-dominated turbid-water state from 1992 to 1994 . Filamentous cyanobacterial species dominated the phytoplanktonic compartment during summer. Bacterial numbers ranged from $2.7 \times 10^{9}$ to $9.8 \times 10^{9}$ cells $^{-1}$, corresponding to biomass values of 35 and $119 \mathrm{\mu g} \mathrm{Cl}^{-1}$, respectively. Temperature, dissolved organic carbon (DOC), primary production and soluble phosphorus were found to explain most of the variation of bacterial numbers and biomass in the system. Bacterial morphotypes exhibited a seasonal succession pattern with rods and vibrios as the most abundant morphotypes. Vibrios dominated during the bloom of cyanobacteria in summer, while rods were found to increase rapidly after the breakdown of the bloom in autumn and winter. Filamentous bacteria with cell lengths of up to $120 \mu \mathrm{m}$ bloomed during a short period in spring, making up more than $60 \%$ of the total bacterial biomass. With principal component analysis we could extract 2 main factors influencing the variation of bacterial morphotypes, namely an abiotic/inorganic factor, containing temperature, oxygen, nitrate and ammonium, and a trophic factor, containing DOC, total nitrogen, total phosphorus and chlorophyll a. Variation of filamentous bacteria, however, could not be explained by these 2 factors. Bacterial secondary production amounted on average to $3.1 \mu \mathrm{g} \mathrm{Cl}^{-1} \mathrm{~h}^{-1}$ with a range from 0.5 to $7.0 \mu \mathrm{g} \mathrm{Cl}^{-1} \mathrm{~h}^{-1}$. The impact of top-down factors like grazing and viral lysis is expected to influence both the occurrence of filamentous bacteria and bacterial production rates. Enzyme kinetics of $\beta$-glucosidase, leu-aminopeptidase and alkaline phosphatase were established and the relations to the other investigated parameters are described. By integrating the phosphatase and aminopeptidase activity into a phosphorus and nitrogen budget for the bacterial and phytoplanktonic compartment in the Alte Donau, we were able to show that there was no P limitation over the whole year, while $\mathrm{N}$ was possibly limiting at the beginning of algal blooms. On an annual basis primary production exceeded by far the bacterial carbon demand, but periods with the reverse situation occurred from October to May. Temperature and carbon supply were seen as the main factors for limiting bacterial growth in the Alte Donau during the cold months. The importance of viral lysis and predation in controlling bacterial growth during the summer months was pointed out. A comparison of the investigated bacterial parameters with those of a mesotrophic but macrophyte-dominated branch of the same backwater system led us to the conclusion that the equilibrium shift of the Alte Donau has resulted in high primary production of the autotrophic procaryotic compartment but not in the expected increase of energy flux through the compartment of the heterotrophic bacterioplankton.
\end{abstract}

KEY WORDS: Backwater system - Eutrophication - Alternative equilibria - Nutrients Bacterioplankton - Morphotypes - Enzyme activities - Bacterial carbon demand

\section{INTRODUCTION}

Since the discussions on the stability and complexity in model ecosystems (Levontin 1969, May 1973) and the consideration of the theoretical possibility that ecosystems may have the potential for more than 1 equilibrium (May 1977, 1981, Scheffer 1990), an increasing documentation of the existence of alternative stable states in freshwater ecosystems could be observed (Hosper 1989, Irvine et al. 1989, Hanson \& 
Butler 1990, Scheffer 1990, Blindow et al. 1993). Shallow lakes seem to be characterized by either abundant submerged macrophytes and clear water at low nutrient concentrations or by abundant phytoplankton and turbid water at high nutrient concentrations (Jeppesen et al. 1990, Moss 1990, Blindow et al. 1993, Scheffer et al. 1993)

A shift from a macrophyte-dominated system to a phytoplankton-dominated one was recorded for the Alte Donau (Dokulil \& Janauer 1995), which is part of the backwater system of the River Danube near Vienna (Austria). The whole system has been separated from the main stream since the last decades of the 19 th century by a series of embankments, which has led to a complete alteration of the character of the ecosystem, which now exhibits features of a shallow lake system. The reduced hydrological dynamics resulted in terrestrification processes leading to the development of a thick sediment layer and of extensive macrophyte vegetation in the backwater branches (Schiemer 1995). The Alte Donau is fed only by groundwater and precipitation and no tributaries and distributaries exist. Thus, the residence time of this backwater branch is in the magnitude of about $1 \mathrm{yr}$.

The fact that such a shift to an alternative stable state had taken place in the Alte Donau became evident by the total disappearance of the submersed macrophytes between 1992 and 1994 (Dokulil \& Janauer 1995). In the following year, changes in the phytoplanktonic community were recorded (Dokulil \& Mayer 1996, Mayer et al. 1997), leading to a key role of the procaryotic compartment in channeling energy and material through the ecosystem. This was indicated by the fact that the primary producers within the planktonic compartment were dominated by filamentous cyanobacteria, namely Cylindrospermopsis raciborskii and Limnothrix redekei (Dokulil \& Mayer 1996). Filamentous cyanobacteria are known to be grazing resistent and therefore less accessible to zooplankton than eucaryotic phytoplankton cells (Güde 1989, Hawkins \& Lampert 1989, Gliwicz 1990, Gliwicz \& Lampert 1990); additionally, they are considered to be an unsuitable food source for crustaceans (Bernardi \& Giussani 1990 , Haney et al. 1994). Consequently, an important fraction of the photosynthetically produced carhon from the water column is expected to enter the detritus pool as particulate organic matter or to be directly available to the bacterial compartment in the form of exudates. Furthermore, one may assume a potential increase of dissolved and particulate detritus fractions within the system due to the organic matter derived from the decay of dying macrophytes from 1992 to 1994, thus increasing the production potential of the heterotrophic bacterial community. In consequence, we assume that bacterial production is statistically signifi- cantly higher than in those systems where macrophytes are the dominating primary producers. Because no data on biomass or production for phyto- and bacterioplankton are available from the Alte Donau for the situation before the shift took place, our hypothesis was tested by comparing the monitored data with those obtained from a mesotrophic branch of the same backwater system (Mathias et al. 1995, Kirschner \& Velimirov 1997), which exhibits features such as abundant submersed macrophytes, clear water and comparatively low concentrations of inorganic nutrients. Beside this energetic aspect, the nitrogen and phosphorus fluxes through the procaryotic compartment were studied and the key factors limiting microbial activity in the system were elaborated.

Finally, the bacterioplankton community with respect to its morphotype composition and succession pattern was investigated with the aim to reveal potential differences in the morphotype structure of bacterial communities in systems with different stable states.

\section{MATERIALS AND METHODS}

Sampling. Sampling took place from April 1994 to April 1995 at 2 stations on the Alte Donau (Gajewski et al. 1997). The water depth of Stn 1 was on average $3.8 \mathrm{~m}$, varying between 3.6 and $4.0 \mathrm{~m}$; at $\operatorname{Stn} 2$ mean depth was $1.8 \mathrm{~m}$, varying between 1.6 and $2.0 \mathrm{~m}$. Samples were taken from 4 depths at Stn $1(0.5,1.5,2.5$ and $3.5 \mathrm{~m})$ and 2 depths at Stn $2(0.5$ and $1.5 \mathrm{~m})$ with a 2.51 Ruttner sampler and transferred into 11 plastic containers. Subsamples for the measurement of primary production were immediately filled into $100 \mathrm{ml} \mathrm{Win-}$ kler bottles and assayed in situ (see below). The samples were transferred to the laboratory in cooling bags (dark and at in situ temperature) within $1 \mathrm{~h}$.

Physical and chemical parameters. Concurrently with sampling temperature, $\mathrm{pH}$ and oxygen were measured in situ at each depth with a multi-parameter probe (Hydrolog 2100; Grabner Instruments, Vienna).

For determination of the chemical parameters, pooled samples from all depths were used. Total phosphorus $\left(P_{t_{i}}\right.$ after dissolution of the unfiltered sample with potassium-peroxydisulfato), dissolved phospho rus $\left(\mathrm{P}_{\mathrm{s}}\right.$; after dissolution of the filtered sample) and soluble reactive phosphorus $\left(\mathrm{P}_{5 r}\right.$ in the untreated filtrate) were determined photometrically using the molybdene-blue method according to Strickland \& Parsons (1968). Total organic nitrogen (after dissolution of the unfiltered sample with sulfuric acid and hydrogeniumperoxide), dissolved organic nitrogen (after dissolution of the filtered sample) and $\mathrm{NH}_{4}$ (in the untreated filtrate) were measured with the indophenolic-blue method according to Parsons et al. (1984). $\mathrm{NO}_{3}$ was 
determined photometrically with the sodium-salicylate method after Legler (1988). Total nitrogen $\left(\mathrm{N}_{\mathrm{t}}\right)$ was calculated as the sum of total organic nitrogen, $\mathrm{NH}_{4}$ and $\mathrm{NO}_{3}$, and dissolved nitrogen $\left(\mathrm{N}_{5}\right)$ was calculated as the sum of dissolved organic nitrogen (DON), $\mathrm{NH}_{4}$ and $\mathrm{NO}_{3}$. All photometrical measurements were performed with a Hitachi U-2000 photometer.

Dissolved organic carbon, chlorophyll a and primary production. For the determination of dissolved organic carbon (DOC) water samples were filtered through precombusted $\left(550^{\circ} \mathrm{C} ; 2\right.$ h) Whatman $\mathrm{GF} / \mathrm{C}$ filters. The filtrate was transferred into combusted ampoules and stored at $-20^{\circ} \mathrm{C}$ until analysis. DOC was determined using a Shimadzu TOC 5000 after sparging the sample with $\mathrm{CO}_{2}$-free air. Standards were prepared with potassium hydrogen phthalate (Kanto Chemical Co., Inc.); a platinum catalyst on quartz was used. Chlorophyll a (chl a) was measured spectrophotometrically (Hitachi U-2000) at wavelengths of 750 and $665 \mathrm{~nm} .50$ to $100 \mathrm{ml}$ of each sample were filtered through a Whatman GF/F filter $(0.7 \mu \mathrm{m}$ nominal pore size), followed by extraction for $1 \mathrm{~h}$ at $80^{\circ} \mathrm{C}$ with $90 \%$ ethanol (Nusch 1980).

Primary production was determined for each depth using the radiocarbon method developed by Vollenweider (1974). $100 \mathrm{ml}$ samples were incubated in situ with $1 \mathrm{ml}$ of ${ }^{14} \mathrm{C}$-sodium bicarbonate $\left(148 \mathrm{kBq},{ }^{14} \mathrm{C}\right.$ Agency, Denmark) for $4 \mathrm{~h}$ and thereafter transported to the laboratory in the dark. $10 \mathrm{ml}$ subsamples were transferred into $20 \mathrm{ml}$ scintillation vials (Canberra Packard) and assayed according to the acid bubbling method (Riemann \& Jensen 1991) to determine the radioactivity incorporated by the phytoplankton. $10 \mathrm{ml}$ of scintillation cocktail were added and radioactivity was measured in a Canberra Packard scintillation counter (1900 TR). Counts were automatically corrected for quenching using a stored standard curve and a machine counting efficiency program.

Bacterial abundance, cell volumes and biomass. For estimation of bacterial numbers and biomass, $20 \mathrm{ml}$ subsamples were fixed with $1 \mathrm{ml}$ buffered formaldehyde $(33 \% ; \mathrm{pH}=8)$, and stored at $4^{\circ} \mathrm{C}$ in the dark for less than 2 wk. For microscopic examination, a slightly modified version of the acridine-orange direct count method after Hobbie et al. (1977) was applied, as described in detail by Kirschner \& Velimirov (1997). Bacteria were classified into 4 groups according to their different morphology: rods, cocci, curved rods (vibrios, including spirillae) and filamentous bacteria. Cells were defined as rods, if their length and width differed by more than $0.2 \mu \mathrm{m}$ (Velimirov \& WalentaSimon 1992). Bacteria longer than $3 \mu \mathrm{m}$ and showing a diameter smaller than or equal to $0.5 \mu \mathrm{m}$ were defined as filamentous forms (Kirschner \& Velimirov 1997). Bacteria were sized by eyepiece micrometer. Details on the calibration of the sizing procedure are published in Velimirov \& Walenta-Simon (1992). At least 20 eyefields per sample were counted and 160 to 200 cells were measured (> 40 per morphotype). Cellular carbon content in fg $\mathrm{C} \mathrm{cell}^{-1}(C)$ was calculated from estimated cell volumes ( $\left.V ; \mu^{3}\right)$ assuming the allometric relation $C=120 \mathrm{~V}^{0.72}$ after Norland (1993).

Bacterial secondary production. Bacterial secondary production was determined by the ${ }^{14} \mathrm{C}$-leucine incorporation method (Simon \& Azam 1989). $10 \mathrm{ml}$ triplicates of each depth were dispensed into a series of $20 \mathrm{ml}$ polyethylene vials and supplemented with a constant amount of ${ }^{14} \mathrm{C}$-leucine $\left(325 \mathrm{mCi} \mathrm{mmol}^{-1}\right.$; $\mathrm{NEN}$ Research Products) to a final concentration of 40 to $60 \mathrm{nM}$. The adequate concentrations were determined bimonthly in saturation experiments and revealed that saturation occurred at concentrations no higher than $60 \mathrm{nM}$. All samples were incubated for $30 \mathrm{~min}$ at in situ temperature; triplicate blanks were killed with formaldehyde (final conc. $4 \%$ ) prior to incubation. Proteins were precipitated by adding trichloroacetic acid (final. conc. $5 \%$ ) and boiling for $30 \mathrm{~min}$ to solubilize DNA. The precipitated proteins were then collected on $0.1 \mu \mathrm{m}$ membrane filters (Sartorius). After addition of $5 \mathrm{ml}$ scintillation cocktail (Ultima Gold; Canberra Packard), radioactivity on the filters was determined in the scintillation counter (see above). Rates of ${ }^{14} \mathrm{C}$ leucine incorporation were converted to bacterial $\mathrm{C}$ production according to Simon \& Azam (1989), assuming a recommended isotope dilution of 2 .

Enzyme activity. Pooled water samples from the different depths were used for enzyme assays. The activity of the enzymes $\beta$-D-glucosidase (E.C. 3.2.1.21), aminopeptidase (E.C. 3.4.1.1) and alkaline phosphatase (E.C. 3.1.3.1) was assayed fluorometrically (Hoppe 1983, Somville \& Billen 1983). We used the nonfluorescent artificial substrates 4 -methyl-umbelliferyl- $\beta$-D-glucose (MUF-GLC ${ }_{i}$ Sigma), L-leucine-4methyl-7-coumarinylamide (LEU-MCA; Fluka) and methyl-umbelliferyl-phosphate (MUF-P; Sigma); after enzymatic hydrolysis we measured the release of the fluorescent products 4-methyl-umbelliferone (MUF) in the case of MUF-GLC and MUF-P while LEU-MCA led to the release of 7-amino-4-methyl-coumarin (AMC). MUF fluorescence was determined at a $366 \mathrm{~nm}$ excitation and a $464 \mathrm{~nm}$ emission wavelength. AMC fluorescence was measured at a $380 \mathrm{~nm}$ excitation and a $440 \mathrm{~nm}$ emission wavelength. The spectrofluorometer (F-2000, Hitachi) was calibrated with standard solutions (final conc. ranging from 1 to $2000 \mathrm{nM}$ ) of MUF (Sigma) and AMC (Fluka), Substrate solutions were prepared with ultra pure Milli-Q water, yielding final sample concentrations of $25,12.5,6.3,3.2$ and $1.6 \mu \mathrm{M}$ for MUF-GLC, 100, 50, 25, 12.5 and $6.3 \mu \mathrm{M}$ for LEUMCA and 10, 5, 2.5, 1.3 and $0.6 \mu \mathrm{M}$ for MUF-P. Incu- 
bation was stopped after $2 \mathrm{~h}$ for MUF-P and LEU-MCA and after $4 \mathrm{~h}$ in the case of MUF-GLC. Increase in fluorescence was linear for this period (data not shown). Blanks were determined by measuring fluorescence immediately after the addition of the substrate. The enzymatic reaction followed Michaelis-Menten kinetics and the plot of the reaction velocity ( $v$ ) against the added concentration of substrate ([S]) gave a rectangular hyperbola according to the equation $v=\left(V_{\max }[\mathrm{S}]\right)$ $\left(K_{\mathrm{m}}+[\mathrm{S}]\right)^{-1}$, where $V_{\max }$ describes the velocity of the reaction which is theoretically attained at an infinitive concentration of substrate $([\mathrm{S}])$, and $K_{\mathrm{m}}$ is the Michaelis-Menten constant representing the substrate concentration where half of $V_{\max }$ is achieved. Kinetic parameters were calculated using the PC program 'Enzfitter' (Elsevier Biosoft) to determine the best fit of the rectangular hyperbola (Leatherbarrow 1987).

Statistical analysis. All statistical analyses were performed with the IBM PC program 'Statistica for Windows 4.0' (Statsoft Inc. 1993). ANOVA was used to test for significant differences between depths and locations. For the following analyses only mean values of the investigated depths were used. Principal component analysis (PCA, varimax-normalized) was performed to evaluate the parameters which were mainly responsible for the observed biological variations in the Alte Donau. For ANOVA, simple linear correlation, multiple linear, stepwise regression analysis and PCA analyses data not meeting the requirements of homoscedaticity and normal distribution (Shapiro-Wilks test) were $\log _{10^{-}}$ transformed after adding 1 to the variable.

\section{RESULTS}

In general, results from both investigated stations were similar. Thus, only Stn 1 was considered in the text and most figures. For statistical analyses and integrative calculations on material fluxes in the system, data from Stn 2 were included.

\section{Physical and chemical parameters}

The water temperature during the investigation period varied from $3.7^{\circ} \mathrm{C}$ in February to $26.1^{\circ} \mathrm{C}$ in the middle of August (Fig. 1A). During January an extensive ice layer covered the Alte Donau, making sampling impossible. During the major part of the year no stratification could be observed, with the exception of June 28 and July 25 , when the temperature at $3.5 \mathrm{~m}$ depth was about $3.5^{\circ} \mathrm{C}$ lower than at the surface. Stn 2 was too shallow to exhibit stratification of any measured parameter. The $\mathrm{pH}$ of the Alte Donau decreased markedly with depth during summer (Fig. 1B), with

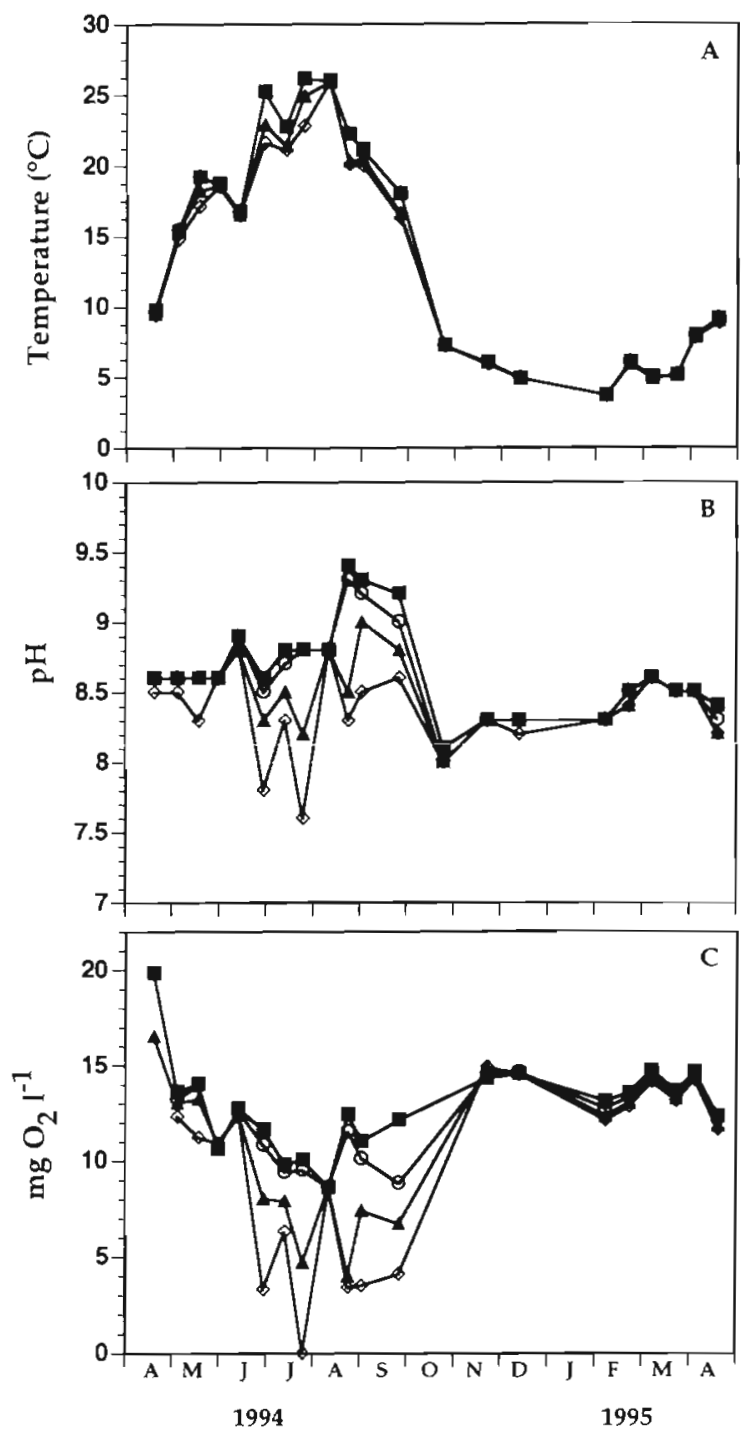

Fig. 1. (A) Water temperature, (B) pH and (C) oxygen concentration in different water depths at $\operatorname{Stn} 1 ; \boldsymbol{\square}: 0.5 \mathrm{~m}, 0: 1.5 \mathrm{~m}$, $\Delta: 2.5 \mathrm{~m}, \diamond: 3.5 \mathrm{~m}$

maximal values of 9.4, measured at the end of August at the surface, and minimal values of 7.6, measured on July 25 in the bottom layer. During autumn and winter rather constant values were recorded. A similar pattern could he nhserved for the oxygen content (Fig, 1C), which exhibited a steep gradient with water depth during the warmer months. Values ranged from $0.0 \mathrm{mg} \mathrm{O} \mathrm{I}^{-1}$ on July 25 above the sediment to $19.8 \mathrm{mg}$ $\mathrm{O}_{2} \mathrm{l}^{-1}$ on April 19 (1994) at the surface and were generally lower during summer than during the cold period mainly due to the minor solubility of oxygen at higher temperatures. Total nitrogen varied between $0.5 \mathrm{mg} \mathrm{N}^{-1}$ in July 1994 and $4.1 \mathrm{mg} \mathrm{N}^{-1}$ at the end of September (Fig. 2A). The dissolved fraction thereof showed a course similar to that of total N. Nitrate con- 


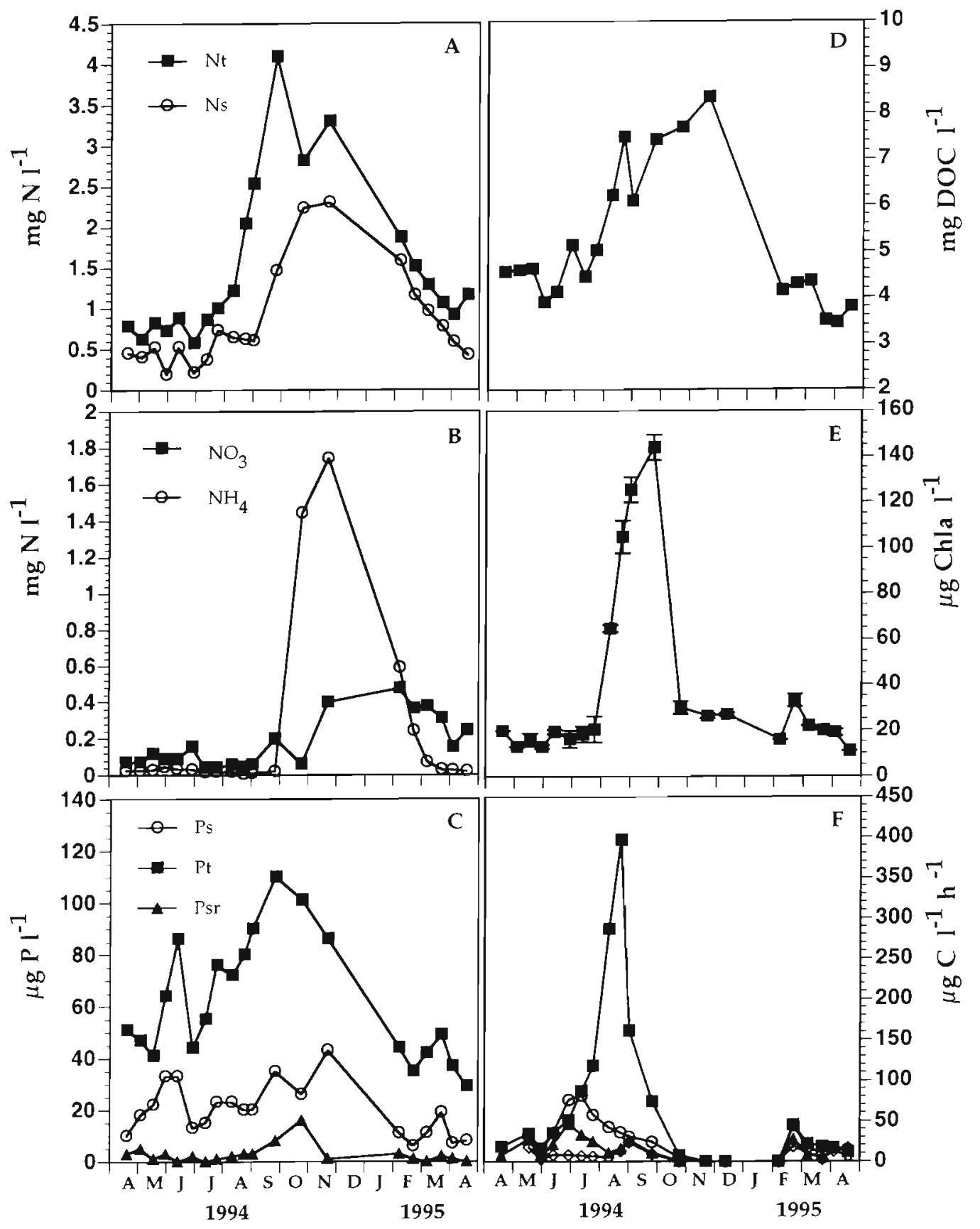

Fig. 2. (A) Total nitrogen $\left(N_{1}\right)$ and dissolved nitrogen $\left(N_{5}\right)$, (B) nitrate and ammonium, $(C)$ total phosphorus $\left(P_{1}\right)$, dissolved phosphorus $\left(\mathrm{P}_{\mathrm{s}}\right)$ and soluble reactive phosphorus $\left(\mathrm{P}_{\mathrm{sr}}\right),(\mathrm{D})$ dissolved organic carbon (DOC), (E) chlorophyll a (chl a), and $(\mathrm{F})$ primary production rates at Stn 1. (A, B, C, D) Values of an integrated water sample; (E) mean of 4 depths \pm 2 standard deviations; (F) $\mathbf{\square}: 0.5 \mathrm{~m}, 0: 1.5 \mathrm{~m}, \boldsymbol{\Delta}: 2.5 \mathrm{~m}, \diamond: 3.5 \mathrm{~m}$

centrations (Fig. 2B) exhibited maximal values during winter, while during the warm period values around $0.1 \mathrm{mg} \mathrm{N} \mathrm{l}^{-1}$ were observed. However, during the major part of the year, nitrate was the main source of inorganic nitrogen, whereas only from October to February did ammonium concentrations exceed by far the amount of nitrate, reaching values of $1.7 \mathrm{mg} \mathrm{N}^{-1}$. Total phosphorus levels of up to $110 \mu \mathrm{g} \mathrm{P}^{-1}$ were observed at the end of September 1994, when the algal bloom reached its maximum (Fig. 2C). The dissolved fraction followed in general the variation pattern of $P_{t}$, except that the autumn maximum occurred 2 mo later. Soluble reactive phosphorus $\left(\mathrm{P}_{\mathrm{sr}}\right)$ ranged from below detection limit to highest values of $16 \mu \mathrm{g} \mathrm{P} \mathrm{l}^{-1}$ in October 1994. 


\section{DOC, chl a and primary production}

DOC ranged from lowest values of $3.2 \mathrm{mg} \mathrm{DOC}^{-1}$ in April 1994 to highest values of $8.4 \mathrm{mg} \mathrm{l}^{-1}$ at the end of November (Fig. 2D). Low DOC concentrations were observed in spring 1994, thereafter increasing strongly from the middle of June until September, concomitantly with the development of the cyanobacterial bloom, as documented by Dokulil \& Mayer (1996). Highest DOC concentrations, however, were recorded at both stations in November, after the fast decline of chl $a$ in October (Fig. 2E). During winter, values dropped again to the same level as in spring 1994. Chl a exhibited a marked peak in September with values of more than $130 \mu \mathrm{g} \mathrm{l}^{-1}$ (Fig. 2E). The drastic increase in chl a during August and September was caused by a fast increase of filamentous cyanobacteria (Cylindrospermopsis raciborskii and Limnothrix redekei, microscopic observation), contributing more than $90 \%$ to total phytoplanktonic biomass (Dokulil \& Mayer 1996). Even during winter chl a values remained above $11 \mu \mathrm{g}^{-1}$. No significant difference in chl $a$ values could be observed between the investigated depths. Phytoplanktonic primary production was below detection limit during the period from December to the beginning of February. Maximal rates of $400 \mu \mathrm{g} \mathrm{C} \mathrm{I}^{-1} \mathrm{~h}^{-1}$ were measured at $0.5 \mathrm{~m}$ depth at the end of August and September (Fig. 2F). During the summer bloom primary production showed a steep decrease with depth. In the middle of February 1995 , concomitant with a small peak in chl a concentration, a peak in primary production could be observed.

\section{Bacterial abundance, cell volumes and biomass}

Over the year, no statistically significant difference could be detected for the bacterial abundance within the water depths. Nevertheless, on 2 dates during the year (June 28 and July 25) bacterial numbers in the water layer above the sediment were significantly lower than in the upper part of the water column $(p<0.05)$. Mean values over all depths ranged from $1.7 \times 10^{9}$ cells $^{-1}$ on May 4, 1994, and increased to $9.8 \times 10^{9}$ cells $l^{-1}$ in December 1994. Thereafter, densities started to decrease again and during February cell numbers dropped rapidly from $7.4 \times 10^{9}$ to $2.7 \times 10^{9}$ cells $^{-1}$ within $2 \mathrm{wk}$ at

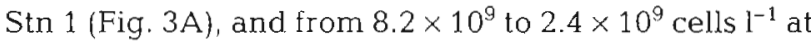
Stn 2 (data not shown). The 4 different morphotypes exhibited a distinct seasonal succession pattern (Fig. 3A,B). At both stations the variation pattern was similar, with the exception of October 25, when a peak of filamentous bacteria was observed at Stn 2 (data not shown). Rods, representing on average $53.4 \%$ (SD: $14.3 \%$ ) of total bacterial numbers, were - with the exception of 2 periods the most abundant morphotype throughout the year. At the end of May vibrio-shaped cells accounted for about $60 \%$ of total bacterial numbers, and during August and September vibrio-shaped cells again were the most abundant morphotype, with a maximum of $78 \%$ of total numbers. On average vibrios contributed $35.7 \%$ (SD: $16.4 \%$ ) to total bacterial numbers. In April 1994 and in the period from February to April 1995, the contribution of filamentous forms to total bacterial numbers (19.4 and 5.3 to $6.3 \%$, respectively) was definitely higher than during the rest of the year (mean: $4.1 \%$; SD: $3.7 \%$ ) at Stn 1 . At Stn 2 at the end of October an additional peak $(16.8 \%)$ was observed, which could not be detected at Stn 1 . Cocci made up on average $7.4 \%$ (SD: $4.0 \%$ ) over the year. Mean bacterial cell volumes varied between 0.035 and $0.180 \mu^{3}$ (Fig. 3C). No statistically significant difference among the investigated depths could be observed at either station. During the major part of the year, namely from May 1994 till the beginning of February 1995, mean cell volumes were small, ranging from

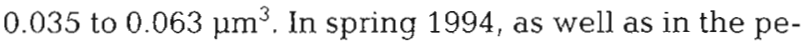
riod from February to April 1995, mean cell volumes had increased and ranged from 0.116 to $0.173 \mu^{3}$, due to a massive bloom of filamentous bacteria. In October, the occurrence at Stn 2 of high filament numbers led to the highest recorded value of $0.181 \mu^{3}$ (data not shown). Mean cell volumes of rod-shaped bacteria over the year varied from 0.025 to $0.072 \mu^{3}$; vibrio-shaped bacteria exhibited cell volumes between 0.025 and $0.094 \mathrm{\mu m}^{3}$. Variation of coccal cell volumes was negligible 10.008 to $0.018 \mu^{3}$, data not shown), whereas average cell volumes of filamentous bacteria ranged from $0.35 \mu \mathrm{m}^{3}$ in May 1994 to a maximal value of $1.98 \mu \mathrm{m}^{3}$ in February and March 1995 (Fig. 3D). Total bacterial biomass varied from $35.2 \mu \mathrm{g} \mathrm{C} \mathrm{l}^{-1}$ at the beginning of May 1994 to $119.2 \mu \mathrm{g} \mathrm{Cl}^{-1}$ in December (Fig. 3E). No statistically significant difference was observed between depths at either station. In general, variation of bacterial biomass followed the pattern of bacterial numbers, with the exception of the periods where filamentous bacteria dominated the bacterioplankton community. As was the case with bacterial numbers, an evident succession pattem of the 4 morphotypes was observed (Fig. 3E,F). Rods contributed on average $43.4 \%$ (SD: $14.4 \%$ ) to the total bacterial biomass over the year. Two periods of much lower contribution were observed, namely during Anril, when filamentous bacteria were abundant, and during August and September, when vibrio-shaped bacteria were the dominating morphotype. At Stn 2 a lower contribution was also caused by filamentous bacteria in October. Vibrio-shaped cells contributed on average $32.5 \%$ (SD: $15.7 \%$ ) to the total bacterial biomass over the year. During September their contribution amounted to more than $60 \%$, while during April 1994 and the period from February to April 1995 only about $20 \%$ of the bacterial biomass was represented by vibrios. At the end of May 1994 


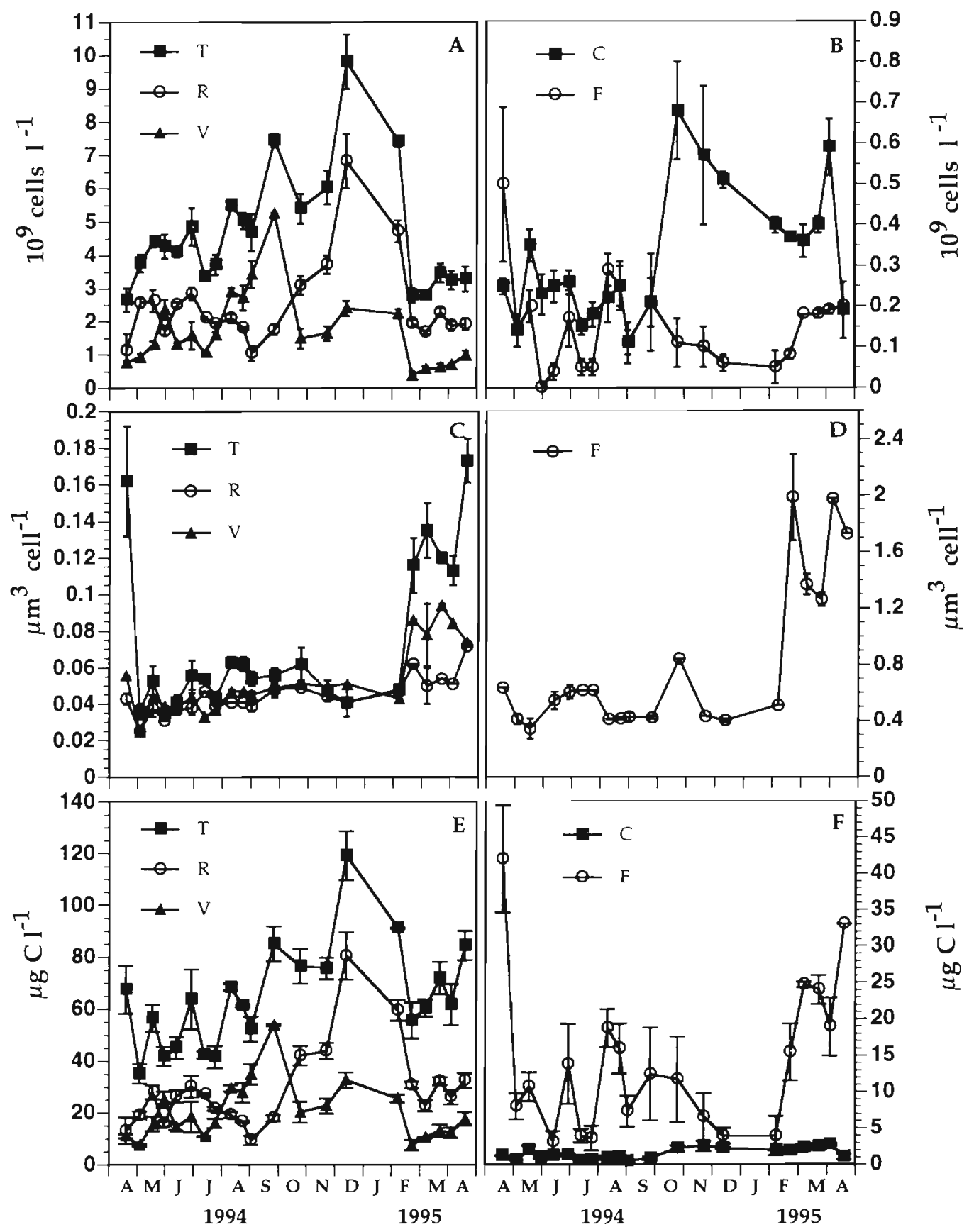

Fig. 3. (A, B) Numbers, (C, D) cell volumes and (E, F) biomass of total bacteria (T), rods (R), vibrios (V), cocci (C) and filamentous bacteria (F) at Stn 1. Bars represent 2 standard deviations of the data from the 4 depths

another peak with values around $60 \%$ was observed at both stations. Coccal biomass averaged $2.3 \%$ (SD: 1.1 ) over the investigation period, thus being rather negligible throughout the year. Filamentous bacteria, however, exhibited biomass maxima during April 1994 and the period from February to April 1995, when values of $62 \%$ (Stn 1) and 44\% (Stn 2) of total bacterial biomass were reached. At Stn 2 one additional peak was observed at the end of October with a value of $63 \%$.

\section{Bacterial leucine incorporation and secondary production}

Bacterial leucine incorporation values followed a similar pattern at both stations (Fig. 4) and ranged from $19 \mathrm{pmol} \mathrm{l}^{-1} \mathrm{~h}^{-1}$ at the beginning of February 1995 to $2550 \mathrm{pmol} \mathrm{l}^{-1} \mathrm{~h}^{-1}$ at the end of July, corresponding to 0.07 and $9.3 \mu \mathrm{g} \mathrm{C} \mathrm{l}^{-1} \mathrm{~h}^{-1}$, respectively. No statistically significant difference could be detected between the 


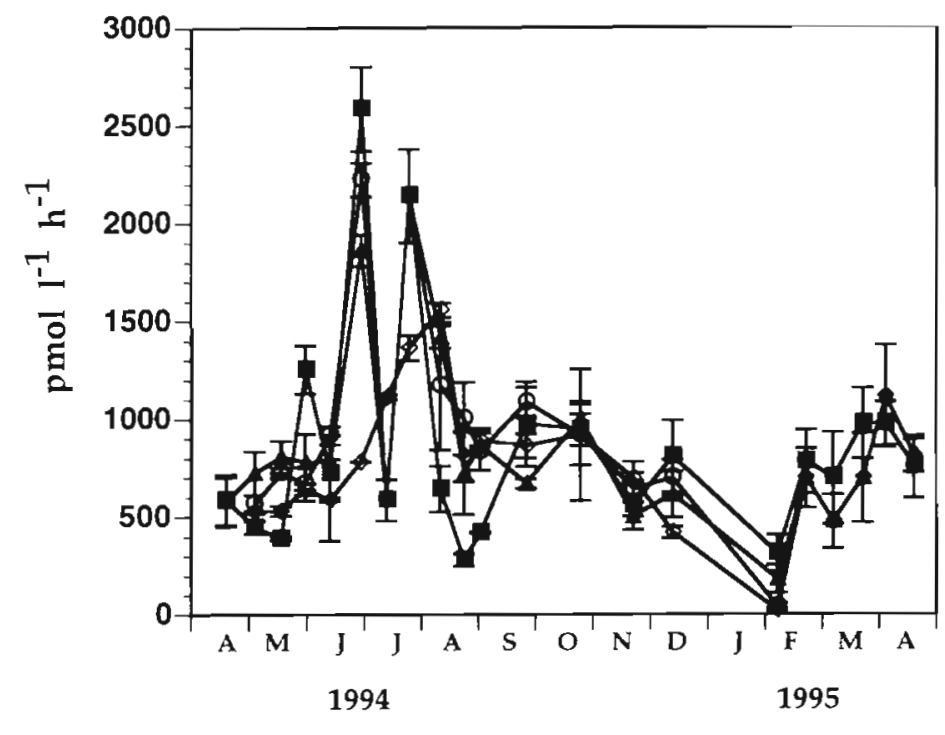

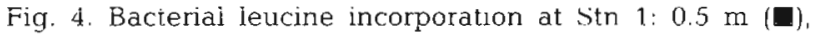
$1.5 \mathrm{~m}(\mathrm{O}), 2.5 \mathrm{~m}(\boldsymbol{\Delta}), 3.5 \mathrm{~m}(\diamond)$; bars represent 2 standard deviations of 3 replicates

depths over the year. However, on June 28 and July 25 significantly lower production values were observed in the layer above the sediment at Stn 1, when a stratification of the water column occurred ( $p<0.05$ ). Calculated turnover times of the bacterial community were longest in February, with values of $90 \mathrm{~h}$ (Stn 1) and $160 \mathrm{~h}$ (Stn 2). At the end of July the turnover time amounted to $6 \mathrm{~h}$, indicating that the bacterial community in the Alte Donau was renewed 4 times per day. Over the year, mean turnover time was about $1 \mathrm{~d}$.

\section{Enzyme activity}

Lowest $V_{\max }$ values of all investigated enzymes were exhibited by the enzyme $\beta$-glucosidase during the whole investigation period, ranging from 2.5 to $27.2 \mathrm{nmol}^{-1} \mathrm{~h}^{-1}$ (Fig. 5A). The apparent MichaelisMenten constant varied from 0.3 to $6.0 \mu \mathrm{M}$ (Fig. 5B). $V_{\max }$ values of aminopeptidase ranged from 142 to $1198 \mathrm{nmol} \mathrm{l}^{-1} \mathrm{~h}^{-1}$ (Fig. 5C). Calculated $K_{\mathrm{m}}$ values were rather constant over the year, ranging from 7.7 to $15.5 \mu \mathrm{M}$, with the exception of April 1994 at Stn 1. when a value of $3.8 \mu \mathrm{M}$ was recorded (Fig. 5D), and of February 7, 1995, at Stn 2, when a value of $25 \mu \mathrm{M}$ was recorded. Alkaline phosphatase displayed the highest $V_{\text {max }}$ values of the 3 investigated enzymes and varied from 71 to $5070 \mathrm{nmol}^{-1} \mathrm{~h}^{-1}$ (Fig. 5E). Maximum values at $\operatorname{Stn} 2$ were much lower than at $\operatorname{Stn} 1 . K_{\mathrm{m}}$ values were in the range of 0.3 to $22.8 \mu \mathrm{M}$ and followed a similar pattern to those of $V_{\max }$ over the year, with maximal values during the phytoplankton bloom in August and September and much lower values during the rest of the year (Fig. 5F).

\section{DISCUSSION}

Because of the lack of submerse macrophytes, planktonic bacteria in the Alte Donau were expected to be tightly coupled to the phytoplankton community, which was the remaining dominant primary producer. This could be shown at different levels concerning seasonal succession, enzymatic activity, as well as carbon and energy flux, discussed in detail in separate sections below.

\section{Seasonal dynamics of bacterial numbers, biomass and production}

Bacterial numbers were significantly correlated to DOC at both stations ( $p<0.01$; Table 1$)$ and reached maximum values of $10 \times 10^{9}$ cells $1^{-t}$ at the beginning of December. After the phytoplanktonic summer bloom (Fig. 2D,F), which was mainly due to an intense development of filamentous cyanobacteria (Dokulil \& Mayer 1997), highest concentration levels of DOC were observed (Fig. 2B), caused by the release of organic matter from senescing and dying cells, thus supporting a dense heterotrophic bacterial population. After December bacterial numbers declined rapidly, concurrently with a steep decrease in DOC values. Within 2 wk in February 1995 bacterial densities dropped from $7.4 \times 10^{9}$ cells $1^{-1}$ (Stn 1 ) and $8.1 \times 10^{9}$ cells $\mathrm{I}^{-1}$

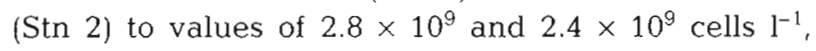
respectively. Physical losses like sedimentation of bacterial cells might be a possible explanation; however, there is no obvious reason why this mechanism should be more effective than during other periods. Thus, we believe that grazing and viral lysis must have been at least responsible for the removal of $4.6 \times 10^{9}$ bacterial cells $\mathrm{l}^{-1}$ at $\operatorname{Stn} 1$ and $5.3 \times 10^{9}$ bacterial cells $\mathrm{l}^{-1}$ at $\operatorname{Stn} 2$ during that $2 \mathrm{wk}$ period, leading to an estimated net removal rate of $1.37 \times 10^{4}$ and $1.58 \times 10^{4}$ bacterial cells $\mathrm{ml}^{-1} \mathrm{~h}^{-1}$. At this time bacterial secondary production (BSP) reached minimum values of $0.07 \mu \mathrm{g} \mathrm{C} \mathrm{l}^{-1} \mathrm{~h}^{-1}$ and $0.6 \times 10^{4}$ cells $\mathrm{ml}^{-1} \mathrm{~h}^{-1}$. Although the present state of knowledge does not enable one to decide whether grazing or virus-induced cell lysis is the dominant mortality factor for bacteria. information from another branch of this backwater system indicates that some $1.1 \times 10^{4}$ to $1.8 \times 10^{4}$ cells $\mathrm{ml}^{-1} \mathrm{~h}^{-1}$ can be lysed by phages at periods of low temperature (Mathias et al. 1995). Thus, bacteriophage-induced mortality alone could account for the observed cell decrease, predation by protozoans or zooplanktonic organisms being negligible during phases of low temperature.

Multiple, stepwise, linear regression analysis was performed to reveal which of the measured variables contribute significantly to the variation of bacterial 


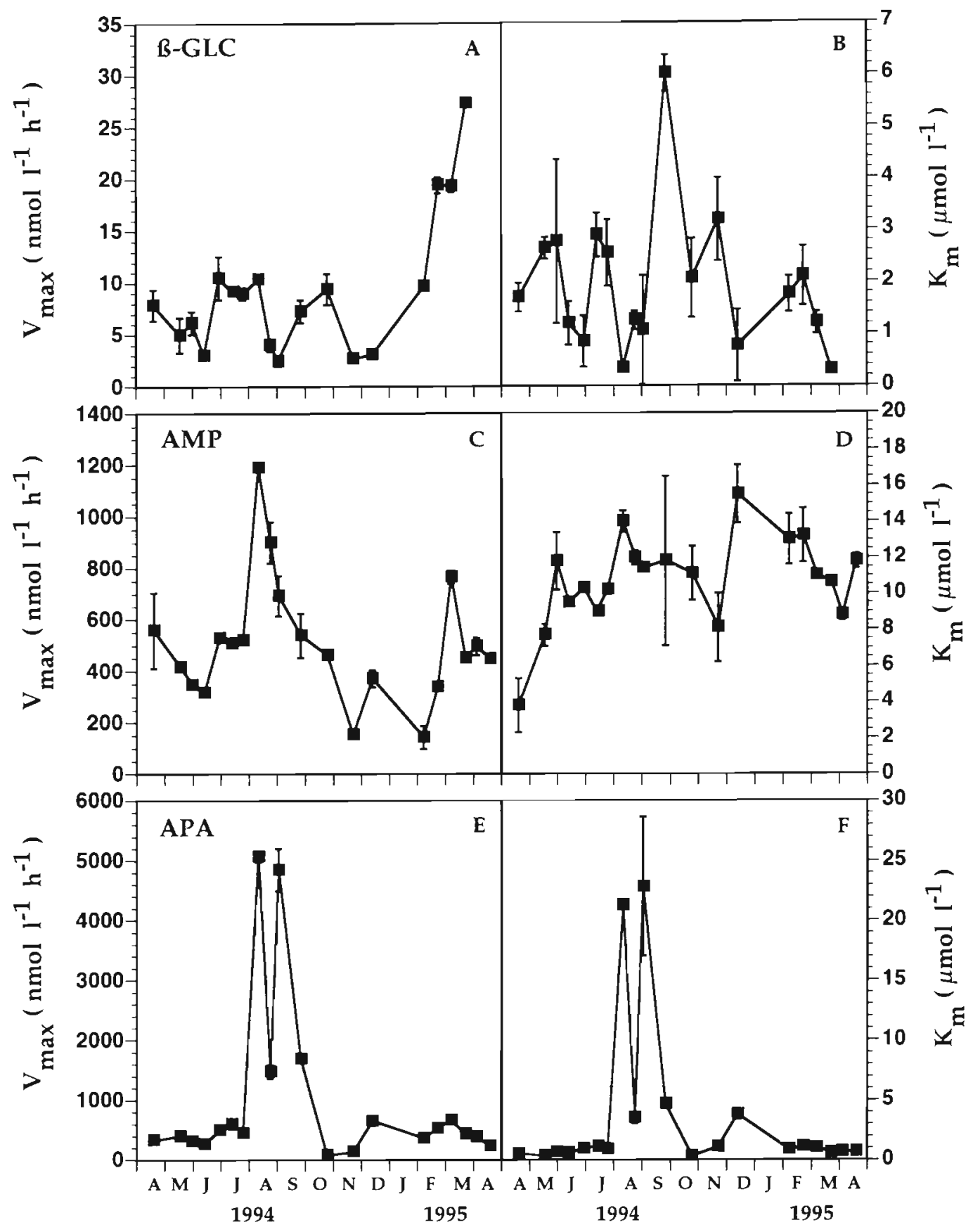

Fig. 5. $V_{\max }$ and $K_{m}$ values of the 3 investigated enzymes $\beta$-glucosidase ( $\beta$-GLC; A, B), leucine-aminopeptidase (AMP; C, D) and alkaline phosphatase (APA; E, F) at Stn 1; bars represent 2 standard deviations of triplicate subsamples of an integrated water sample

numbers and biomass in the Alte Donau. The regression models are presented in Table 2. At Stn 1, temperature, DOC, primary production and $\mathrm{P}_{\mathrm{s}}$ were found to explain $90 \%$ of the total variation of bacterial numbers. At Stn 2, the partial regression coefficient of DOC was not significant and the other 3 parameters explained $66 \%$ of the variation. For bacterial biomass (BBM) a similar model could be calculated for both stations, with temperature and DOC as significant factors, explaining 45 and $47 \%$ of the total variation, respectively. Surprisingly temperature was negatively correlated to both bacterial numbers and biomass. For an explanation we speculate that on the one hand there might have been an indirect effect via grazing with reduced grazing rates at low temperatures, while on the other hand bacterial numbers and biomass values 


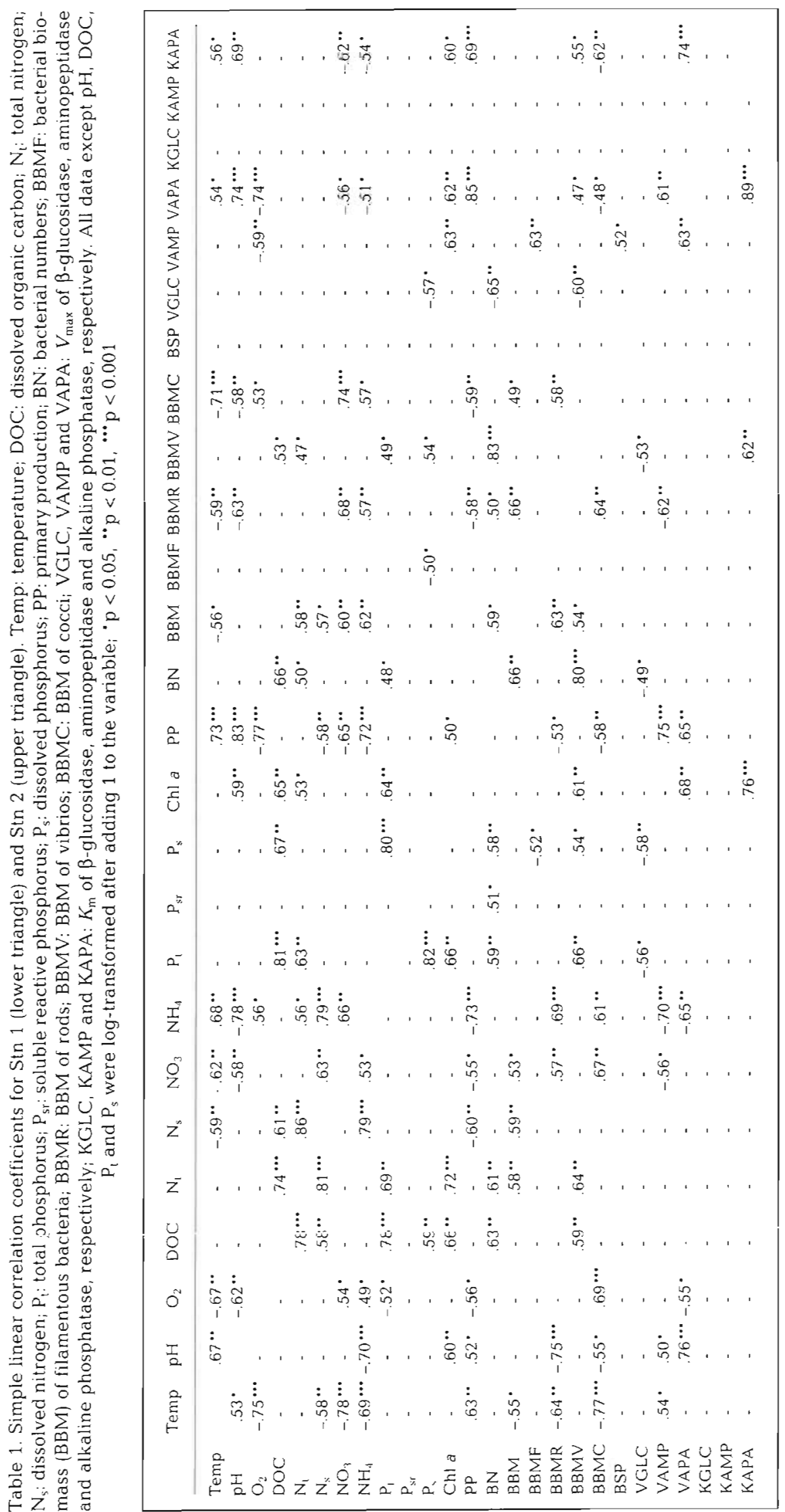

were highest during winter because of the high DOC levels during that time.

BSP showed only a weak positive correlation with temperature in the Alte Donau ( $\mathrm{r}=0.41 ; \mathrm{p}<$ 0.1 ) at both stations. For several freshwater and marine ecosystems (e.g. Wikner \& Hagström 1991, Autio 1992, Pace \& Cole 1994) and for the backwater Kühwörter Wasser (Kirschner \& Velimirov 1997) temperature was found to be significantly correlated to BSP, and Schweitzer \& Simon (1994) presented evidence that bacterial production in temperate freshwater ecosystems is mainly controlled by temperature and substrate. In the Alte Donau none of the BSP peaks coincided with the chl a or DOC maxima, but occurred at the end of June and July. At this time we recorded rather low phytoplanktonic biomass and DOC values, while temperature exhibited its highest values for the year. However, a striking feature was that maxima in bacterial numbers and biomass were found during periods of low temperatures, namely December, thus being uncoupled from the maximum bacterial production events in summer. Although bacterial production ranged from

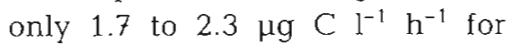
December, corresponding biomasses amounted to $104-119 \mu \mathrm{g}$ $\mathrm{C}^{-1}$ (Fig. 3E), 2 to 3 times higher than in June-July. The fact that such low production rates are sufficient to support high bacterial biomasses is seen as an indication for a weakening of the top-down effect on the bacterial compartment in late autumn and winter as compared to summer.

\section{Bacterial morphotype succession}

The morphotype composition of the bacterioplankton in the Alte Donau changed markedly over 


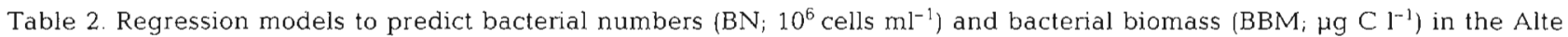
Donau. All regressions represent ordinary least square fits and are significant at $p\left(\mathrm{H}_{0}\right)<0.005$ or stronger. Only mean values of the data from the investigated depths were used. Primary production values are integrated over the water columnn (PP; mg C $\left.\mathrm{dm}^{-2} \mathrm{~h}^{-1}\right)$; Temp: temperature $\left({ }^{\circ} \mathrm{C}\right)$; DOC: dissolved organic carbon $\left(\mathrm{mg} \mathrm{l}^{-1}\right)$; $\mathrm{P}_{\mathrm{s}}$ : dissolved phosphorus $\left(\mu \mathrm{P} \mathrm{P}^{-1}\right)$

\begin{tabular}{|c|c|c|c|}
\hline & Equation & Adjusted $r^{2}$ & $\mathrm{n}$ \\
\hline \multirow[t]{2}{*}{ Stn 1} & $\log (B N)=5.73-0.80 \log ($ Temp +1$)+0.28 \log (P P+1)+0.018 P_{5}+0.84 \log (D O C+1)$ & 0.90 & 19 \\
\hline & $\mathrm{BBM}=47.3-50.6 \log (\mathrm{Temp}+1)+93.1 \log (\mathrm{DOC}+1)$ & 0.45 & 20 \\
\hline \multirow[t]{2}{*}{ Strn 2} & $\log (B N)=6.46-0.74 \log (T e m p+1)+0.27 \log (P P+1)+0.013 P_{s}$ & 0.66 & 19 \\
\hline & $\mathrm{BBM}=45.2-55.5 \log ($ Temp +1$)+102.7 \log (\mathrm{DOC}+1)$ & 0.48 & 20 \\
\hline
\end{tabular}

the year. An alternative occurrence of rods and vibrios dominated the yearly time course of total bacterial numbers (Fig. 3A). At both stations vibrio biomass was significantly positively correlated with $N_{t}, P_{t}, P_{s}$ and DOC (Table 1); in addition, a positive correlation to chl a was found at Stn 1. Biomass of vibrio-shaped bacteria was highest at the end of September, at the same time that chl a values reached their maximum (Figs. 2D \& 3E). Thereafter, a steep decrease could be observed for both parameters. Biomass of rods showed a significant negative correlation with temperature, $\mathrm{pH}$ and primary production at both stations. Lowest biomass values occurred during the cyanobacterial bloom in September. After the breakdown of the bloom rods biomass increased rapidly, coinciding with low chl a and high DOC values. Cocci were rather negligible over the year, contributing on average $2.3 \%$ to the total BBM, but they exhibited a succession pattern similar to that of rod-shaped bacteria, with maxima during late spring and after the cyanobacterial summer bloom. Filamentous bacteria occurred in abundance in spring 1994 and 1995 at both stations, making up more than $60 \%$ of the bacterial biomass (Fig. 3F). At Stn 2, however, another peak of filamentous bacteria was observed at the end of October, with $60 \%$ of the total BBM. Similar observations were previously made by Kirschner \& Velimirov (1997) on a mesotrophic branch (Kühwörter Wasser) of the same backwater system, where filamentous bacterial blooms occurred exclusively in early spring, contributing up to $40 \%$ to the total BBM. This phenomenon can be interpreted as the emergence of grazing-resistant bacteria (Jürgens \& Güde 1994), which are simply too big to be easily consumed by heterotrophic nanoflagellates (HNF). It has been shown recently for the Alte Donau (Wieltschnig et al. unpubl.) that in 1995 HNF exhibited a marked spring peak when biomass of filamentous bacteria was highest. This could indicate that filamentous bacteria might gain a selective advantage in comparison to the other bacterial morphotypes of smaller size, which are preferentially grazed by HNF during this period. Also, the rapid disappearance of the filaments in May is open to speculation. It is expected to result both from direct grazing by metazooplanktonic organisms like cladocerans and copepods, which have a size-limited potential to feed on filamentous bacteria, and which are known to become abundant in spring (Gliwicz \& Pijanowska 1989), as well as from increasing competition for nutrients with the smaller bacteria after the decrease in HNF numbers. Smaller bacteria are usually thought to be stronger competitors for nutrients because of their higher surface to volume ratio. In view of this hypothesis it should be mentioned that no significant correlation was found for the biomass of filamentous bacteria to any measured parameter, indicating that neither physico-chemical parameters nor nutrients, but probably top-down forces, have a significant influence on the variation of this morphotype.

In order to provide a clear overview of the relationship between the measured parameters and the 4 morphotypes, principal component analysis (PCA) was applied. At Strn 1, 3 relevant factors (eigenvalue $>1,0$ ) could be extracted with the PCA (Table 3). Factor 1 can be described as an abiotic/inorganic component, containing temperature, oxygen, nitrate and ammonium, and explains $36 \%$ of the observed variance. Factor 2 is responsible for $31 \%$ of the observed variance and contains DOC, $\mathrm{P}_{t}, \mathrm{~N}_{t}$ and chl $a$, representing the trophic situation of the Alte Donau. The third factor, which explains $13 \%$ of the variance, only contains $P_{5}$. Fig. $6 \mathrm{~A}$ shows the 2-D graphical presentation of the PCA of Stn 1 with the Factors 1 and 2 as $x$ - and $y$-axis, respectively. Cocci and rod-shaped bacteria are clustered with $\mathrm{NO}_{3}, \mathrm{NH}_{4}$ and oxygen, while vibrio-shaped bacteria are tightly coupled to chl $a, D O C, N_{1}$ and $P_{t}$. Filamentous bacteria, on the other hand, are not significantly associated with any other variable, indicating that other factors like grazing are most probably responsible for the observed variation. At Stn 2 the abiotic/inorganic factor (temperature, $\mathrm{NH}_{4}$ and $\mathrm{NO}_{3}$ ) explained only $28 \%$ of the observed variance; the trophic factor 2 (DOC, $\mathrm{N}_{\mathrm{t}}, \mathrm{N}_{\mathrm{s}}, \mathrm{P}_{\mathrm{t}}, \mathrm{P}_{\mathrm{s}}$ and chl a) explained $30 \%$ of the variance at Stn 2 . The third factor explained $17 \%$ of the observed variance and contained 
Table 3. Principal component analysis showing the principal factors with an eigenvalue $>1$ and their explained variance. Variables not being of importance for the variation of the bacterial morphotypes were omitted. With the exception of $\mathrm{P}_{t}$ and $P_{\mathrm{s}}$ data are $\log _{10}$-transformed after adding 1 to the variable. See Table 1 for abbreviations. PC 1-PC 4: principal components $1-4$

\begin{tabular}{|c|c|c|c|c|c|c|c|}
\hline \multirow[t]{2}{*}{ Variable } & \multicolumn{3}{|c|}{ Stn 1} & \multicolumn{4}{|c|}{$\operatorname{Stn} 2$} \\
\hline & PC 1 & PC 2 & PC 3 & PC 1 & PC 2 & PC 3 & $\mathrm{PC} 4$ \\
\hline Temp & -.89 & - & - & -.77 & - & - & - \\
\hline $\mathrm{O}_{2}$ & .70 & - & - & - & - & .84 & - \\
\hline DOC & - & .90 & - & - & .93 & - & - \\
\hline $\mathrm{N}_{\mathrm{t}}$ & - & .92 & - & - & .87 & - & - \\
\hline $\mathrm{N}_{\mathrm{s}}$ & - & - & - & - & - & - & - \\
\hline $\mathrm{NO}_{3}$ & .78 & - & - & .85 & - & - & - \\
\hline $\mathrm{NH}_{4}$ & .89 & - & - & .64 & - & - & - \\
\hline$P_{t}$ & - & .85 & - & - & .89 & - & - \\
\hline$P_{s}$ & - & - & -.73 & - & .74 & - & - \\
\hline Chl a & - & .84 & - & - & 71 & - & - \\
\hline PP & -.81 & - & - & - & - & -.77 & - \\
\hline BBMF & - & - & .88 & - & - & - & .92 \\
\hline BBMR & .79 & - & - & .89 & - & - & - \\
\hline $\mathrm{BBMV}$ & - & .74 & - & - & .65 & - & - \\
\hline $\mathrm{BBMC}$ & 83 & - & - & .78 & - & - & - \\
\hline \multicolumn{8}{|c|}{ Expl. variance $(\%)$} \\
\hline & 35.8 & 30.9 & 13.2 & 27.8 & 29.6 & 16.7 & 10.6 \\
\hline
\end{tabular}

oxygen and primary production (Table 3). A fourth factor was extracted containing only filamentous bacteria and showing again that the measured variables are not responsible for the variation of this morphotype. The 2-D graphical presentation (Fig. 6B) reveals a similar situation as at Stn 1. Rods and cocci are clustered with $\mathrm{NO}_{3}$, while vibrio-shaped bacteria are coupled with DOC, chl $a, N_{1}, P_{t}, N_{s}$ and $P_{s}$.

Although no variables related directly to top-down control were measured, the observed sequence of the 4 morphological groups, the calculated correlations to the measured parameters and the results of the PCA led us to the conclusion that bacterial morphotype succession in the Alte Donau is mainly influenced by abiotic and bottom-up forces over the year, with the exception of a short period during spring, when large bacteria (filamentous forms) are the dominating part of total bacterial biomass, and top-down effects (grazing) as well as competition are rnncidered to he of major importance.

Certainly we are aware that the 4 different morphotypes described here do not coincide with individual bacterial strains, but consist most probably of an unknown number of different species. On the other hand, we know that a big portion of aquatic bacterial populations exist in a dormant state (Stevenson 1978, Moriarty \& Bell 1993, Nyström 1993). Therefore, we cannot exclude the possibility that during certain periods within an annual cycle some bacterial strains gain an enormous selective advantage in comparison to others, so that the majority of the bacterial biomass in the system might consist of only a few species with similar eco-physiological features.

In a comparison with another, but mesotrophic, branch of the same backwater system, the Kühwörter Wasser (Kirschner \& Velimirov 1997), differences were found in the community succession pattern over the year. Maximal bacterial numbers in the Kühworter Wasser occurred in early summer, when vibrio-shaped bacteria dominated the bacterial community, while maximal densities in the Alte Donau were observed in December, when rods were the most abundant morphotype. In addition, the period during which vibrios dominated the bacterial community in summer was shorter in the Kühwörter Wasser than in the Alte Donau. A surprising correspondence was nevertheless observed with the occurrence of blooms of filamentous bacteria in early spring in both systems. This indicates that filamentous bacteria are a characteristic feature in the investigated backwater system of the River Danube, independent of the trophic situation.

\section{Inter-ecosystem comparison}

In general the bacterial densities as well as bacterial biomass in the Alte Donau were in the lower range of other eutrophic and hypertrophic freshwater systems. For a comparison we used only data from seasonal studies and considered also information from shallow lakes since investigations on backwater systems are scarce (Table 4). Extremely high bacterial densities with values up to $157 \times 10^{9}$ cells $\mathrm{l}^{-1}$ were only reported once by Boon (1991) for the Australian billabongs. In most studies (Berninger et al. 1993, Gajewski et al. 1993, Jürgens \& Stolpe 1995, Middelboe et al. 1995, Søndergaard et al. 1995) bacterial numbers reached maxima of $20 \times 10^{9}$ to $30 \times 10^{9}$ cells $\mathrm{l}^{-1}$, while maximal densities reported by Bell et al. (1983) and Pedrós-Alió $\&$ Brock (1982) amounted to $2.4 \times 10^{9}$ and $3.0 \times 10^{9}$ cells $1^{-1}$, respectively. Amblard et al. (1995) found densities of $1.4 \times 10^{9}$ to $7.3 \times 10^{9}$ cells $1^{-1}$ in a eutrophic humic lake, which are the closest values to the data of the $\Delta$ lte Donau as well as the bactcrial biomass values (17 to $190 \mu \mathrm{g} \mathrm{C} \mathrm{l}^{-1}$ ) in the eutrophic Lake Nesjövatn (Vadstein et al. 1989). Surprisingly the data from another, but mesotrophic, branch of the backwater system of the River Danube (Kirschner \& Velimirov 1997) indicated no difference in comparison with the Alte Donau: in the Kühwörter Wasser cell densities ranged from $2.0 \times 10^{9}$ to $9.0 \times 10^{9}$ cells $\mathrm{l}^{-1}$, corresponding to a

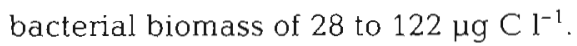

Average bacterial cell volumes were rather constant over the year, ranging mostly between 0.035 and 

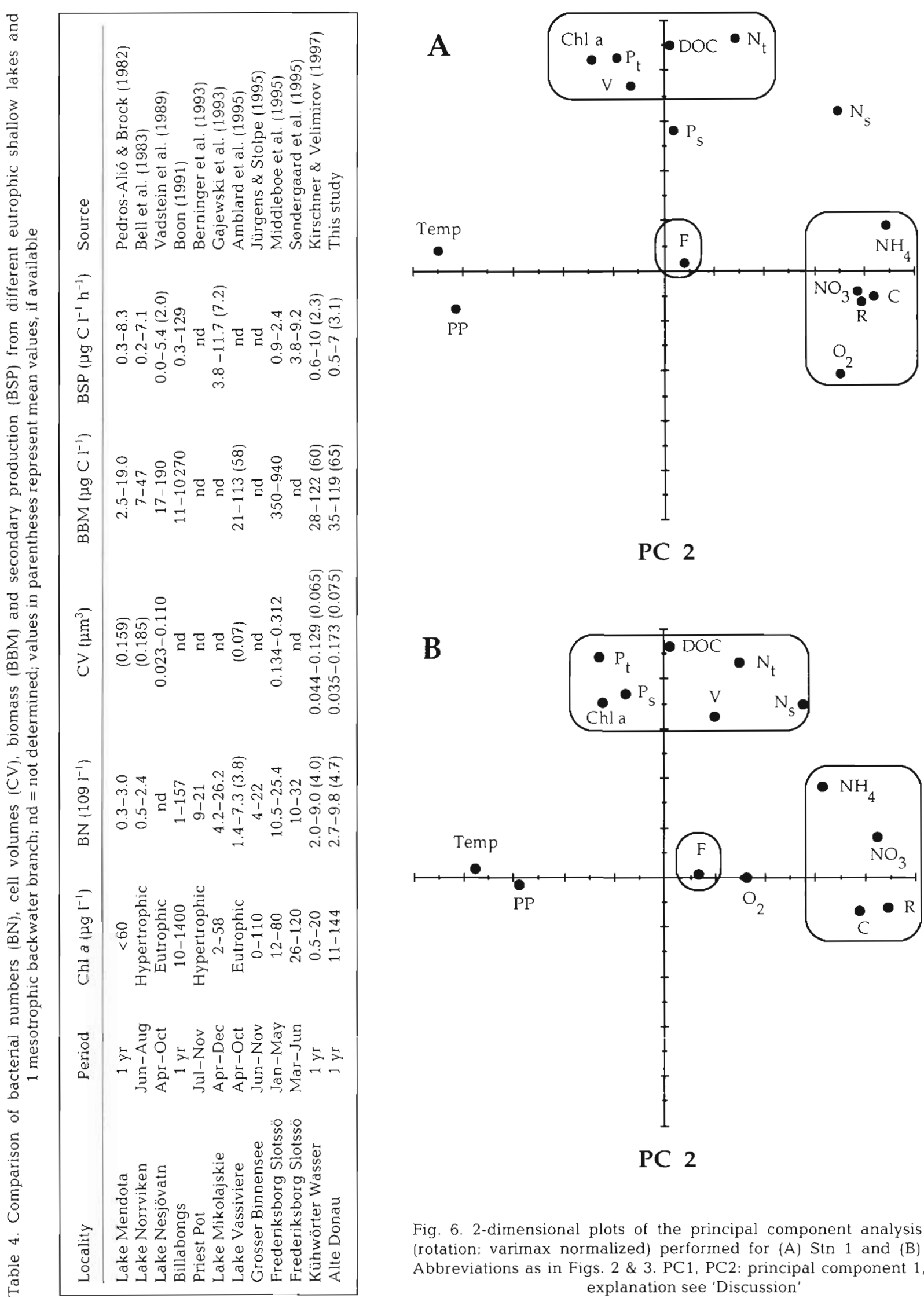

PC 1

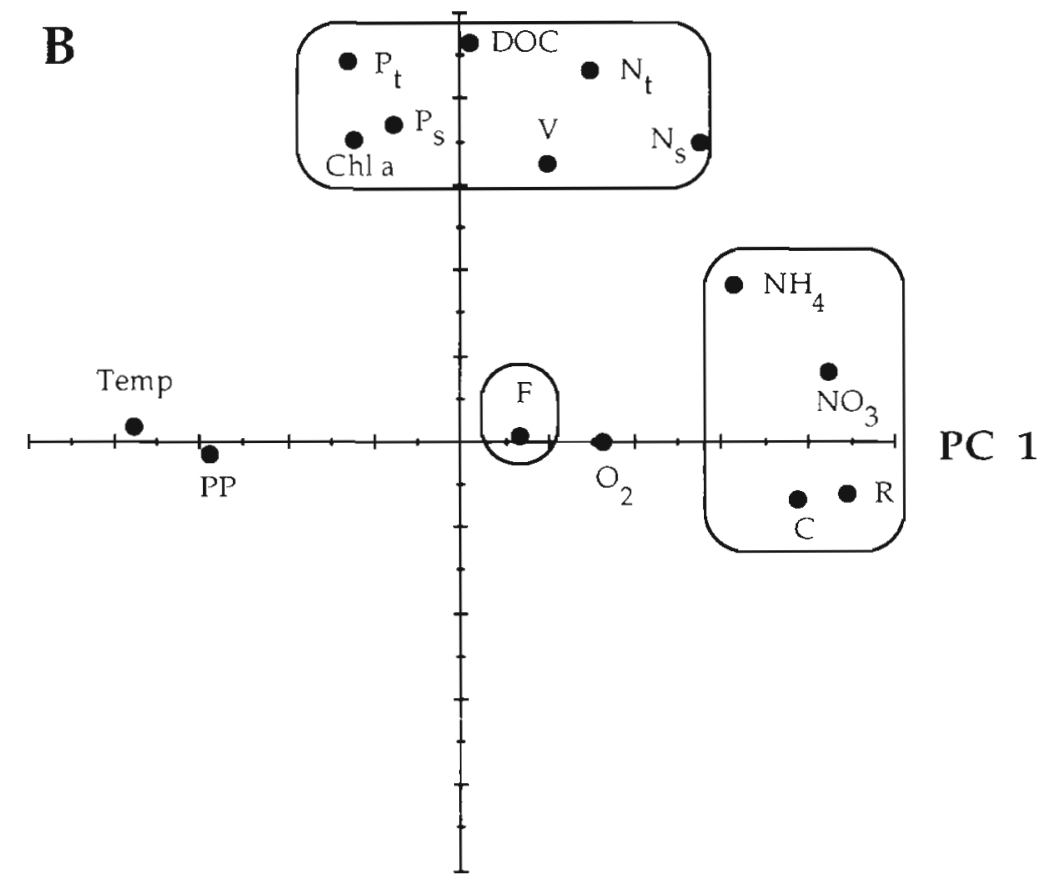

PC 2

Fig. 6. 2-dimensional plots of the principal component analysis (PCA) (rotation: varimax normalized) performed for (A) Stn 1 and (B) Stn 2. Abbreviations as in Figs. 2 \& 3. PC1, PC2: principal component 1, 2. For explanation see 'Discussion' 
$0.060 \mathrm{~mm}^{3} \mathrm{cell}^{-1}$, with the exception of periods when filamentous bacteria dominated the system. In the Kühwörter Wasser (Kirschner \& Velimirov 1997) filaments with a length of up to $60 \mu \mathrm{m}$ were found and were reported to belong to the largest bacteria occurring in the aquatic environment (Sime-Ngando et al. 1991). In the hypertrophic lake 'Großer Binnensee', filament lengths of up to $20 \mu \mathrm{m}$ were found during a bloom in August (Jürgens \& Stolpe 1995). In the present study filamentous bacteria reached a length of up to $120 \mu \mathrm{m}$ $\left(5.6 \mathrm{\mu m}^{3}\right.$ ), thus being twice as long as those in the mesotrophic Kühwörter Wasser and 6 times longer than those in the 'Großer Binnensee'. Cell volumes were only reported in a few studies (Table 4), usually being on average bigger than those in the Alte Donau. Only Amblard et al. (1995) found a mean cell volume of $0.07 \mathrm{~m}^{3}$ in the eutrophic Lake Vassiviere, and in Lake Nesjövatn cell volumes ranged between 0.023 and $0.110 \mu^{3}$ (Vadstein et al. 1989). In the mesotrophic Kühwörter Wasser similar mean cell volumes ranging from 0.044 to $0.129 \mu^{3}$ were measured.

In general BSP rates were in the range of other comparable ecosystems (Table 4 ). With the exception of the Australian billabongs (Boon 1991), maximal production rates were always in the magnitude of the values in the Alte Donau (5.4 to $11.7 \mu \mathrm{g} \mathrm{C} \mathrm{l}^{-1} \mathrm{~h}^{-1}$ ). Therefore, we assume that our BSP rates and the used conversion factors are reliable estimates for the calculation of a carbon budget for the Alte Donau (see below).

\section{Enzyme activity}

Bacterial numbers showed a strong significant negative correlation with $\beta$-glucosidase ( $\beta$-GLC) activity in our system (Table 1). A positive correlation between these 2 parameters was observed by Chróst \& Overbeck (1990) and Chróst (1989) in Lake Plußsee during a phytoplankton bloom. In the Alte Donau, however, this negative correlation might be explained by the fact that $\beta$-glucosidase is an enzyme which is inducible and endproduct controlled. Thus, a low $\beta$-GLC activity indicates a large amount of readily utilizable monoand disaccharids favouring bacterial growth and leading to higher bacterial numbers. At the beginning of the phytoplankton bloom 3 -GLC activity decreased, probably because active algae liberated low molecular weight carbohydrates easily assimilable by microheterotrophs. In October, on the other hand, during the breakdown of the phytoplankton bloom, a peak in $\beta$ GLC activity was observed. High amounts of polymeric carbohydrates are supposed to have been liberated during autolysis of algal cells (Chróst 1989, 1991), inducing the synthesis of $\beta$-GLC. During that period highest $K_{\text {m }}$ values were also recorded, reflecting a very low substrate affinity and indicating again a high concentration of polymeric carbohydrates. From December until the end of the investigation period $\beta$-GLC activity gradually increased to its maximum, while $K_{\mathrm{m}}$ values dropped to their lowest values within the year. During this period low primary production obviously led to a deficit in readily utilizable DOM, thus inducing the production of $\beta$-GLC.

Aminopeptidase activity and the incorporation of leucine into the bacterial biomass were significantly positively correlated over the year at Stn 2 (Table 1). Similar observations were made in other eutrophic ecosystems (Chróst 1989, Chróst \& Rai 1993, Gajewski \& Chróst 1995). However, during the time of high phytoplankton biomass and production (July to September) both processes were uncoupled (Figs. $4 \& 5$ ), probably because phytoplankton released large amounts of amino acids during that period (Münster \& Chróst 1990, and citations therein). Surprisingly the aminopeptidase activity was also significantly positively correlated to algal biomass (Stn 2) and primary production (Stn 1; Table 1). Until now leucine-aminopeptidase (AMP) has been shown to be mainly produced by bacterial cells (Chróst 1991 and citations therein) but not by phytoplankton. Therefore, we do not assume that phytoplanktonic cells are responsible for AMP activity in the Alte Donau. Gajewski \& Chróst (1995) also observed such a correlation in Lake Mikolajskie and concluded that overall bacterial enzymatic activity strongly depends on algal organic matter production. Another explanation might also be an association of attached bacterial cells with cyanobacterial cells, but this was not quantitatively observed in our samples. Nitrate and ammonium were significantly negatively correlated to AMP activity at Stn 1 (Table 1), indicating that at periods with high amounts of readily utilizable inorganic $\left(\mathrm{NO}_{3}, \mathrm{NH}_{4}\right)$ and organic (released by phytoplankton) nitrogen compounds, aminopeptidase production is repressed.

Alkaline phosphatase (APA) exhibited a very strong correlation with primary production and chl a (Table 1). Primary production alone explained 43 and $72 \%$ of the seasonal variation of APA at Stns 1 and 2, respectively, $\mathrm{pH}$ was also significantly positively correlater to APA artivity, ronfirming that this enzyme binds and hydrolyses substrates more efficiently under more alkaline conditions. Algae as well as bacteria have been found to produce alkaline phosphatase when available $\mathrm{P}$ compounds are limiting (Chróst 1991 and citations therein). Highest $V_{\max }$ values were measured during the summer phytoplankton bloom and thereafter dropped to the lowest values recorded during the investigation period. During this period of of cyanobacterial bloom breakdown $\mathrm{P}_{\mathrm{sr}}$ values reached their maximum, indicating that APA synthesis was 


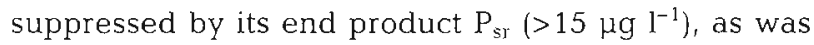
already shown by Siuda \& Chróst (1987) and Chróst \& Overbeck (1987). Apparent $K_{\mathrm{m}}$ values followed the pattern of $V_{\text {max, }}$ and this increase in affinity of the enzyme is explained as an increase in efficiency in binding substrate in situations when soluble phosphorus is low in the system (Fig. 2E). Thus, the high affinity, as reflected by the low $K_{\mathrm{m}}$ values, could be an indication of efficient substrate binding to the reactive site of the enzyme and consequent hydrolysis, which is seen as a useful strategy during periods of low enzyme activity due to low substrate availability. Such a high enzyme affinity is of less importance during periods of high $V_{\max }$ when enzyme systems of the photosynthetic compartment and the heterotrophic bacteria interact in the water column.

\section{Phosphorus budget}

In the following discussion, we attempted to estimate whether the amount of phosphate liberated by enzymatic hydrolyzation could cover the bacterio- and phytoplankton demand in the Alte Donau. In this context it should be mentioned that enzyme activities measured with the fluorogenic substrate method are probably underestimated because of competitive inhibition by the natural substrate. Furthermore, artificial substrates such as those used in our study are not representatives of all naturally occurring substrates, and it is not clear whether these artificial substrate analogues reflect cleavage under natural conditions. Therefore, estimations of $V_{\max }$ and $K_{\mathrm{m}}$ values have to be considered with caution and are mainly used as comparative values in the discussion above.

In a first step we calculated the P demand for the BSP and for the phytoplanktonic primary production using $\mathrm{C}: \mathrm{P}$ conversion factors from the available literature. In the most recent publication (Fagerbakke et al. 1996) $\mathrm{C}: \mathrm{P}$ ratios (wt:wt) for bacteria varying between 11 and 25 (mean: 19), obtained by X-ray analysis of individual seawater bacteria, were reported. Vadstein et al. (1993) found ratios between 2.8 and 27 (mean: 11.6), but did not investigate individual bacterial cells. Only in Vadstein \& Olsen (1989) was bacterial P content measured directly in chemostat cultures and C:P ratios were in the range of 25 to 59 . As the photosynthetically active compartment in the Alte Donau is dominated by cyanobacteria, we chose a C:P ratio of 41 (wt:wt) for the phytoplankton, which was proposed for Oscillatoria limosa by Pucsko (1985) and which is actually the same as the conventional Redfield ratio of 106, usually expressed as a molar ratio.

In a second step the rate of orthophosphate liberated by the activity of the alkaline phosphatase was esti- mated according to the Michaelis-Menten equation, assuming a varying percentage of the dissolved organic phosphorus (DOP) pool as actual substrate concentration ([S]). DOP was calculated by subtracting the soluble reactive $P$ from the dissolved $P$ fraction (Fig. $2 E$ ). However, not all forms of the dissolved organic P were available for enzymatic hydrolysis (Chróst et al. 1986). Chróst \& Overbeck (1987) found that in Lake Plußsee enzymatically hydrolyzable P (EHP) compounds comprised $63 \%$ of the DOP pool. In a series of eutrophic lakes Francko (1984) estimated 0 to $65 \%$ of the DOP fraction to be EHP. Plotting the average orthophosphate release rates at Stns 1 and 2 against increasing EHP percentages, we came to the conclusion that over the year a mean of only $7.5 \%$ (range: 6.5 to $8.5 \%$ ) at Stn 1 and $10 \%$ (range: 9 to $11 \%$ ) at Stn 2 of the DOP pool would have had to have been made up of EHP in order for enzymatic activity alone to cover both the bacterial and algal $P$ demand (Fig. $7 \mathrm{~A}$ ), indicating that the bacterioplankton in the Alte Donau is most probably not $\mathrm{P}$ limited. Range calculations (not shown in Fig. 7A) were based on the upper and lower C:P conversion factors for bacterioplankton from Fagerbakke et al. (1996). Since other phosphatases, such as acid phosphatase or 5'-nucleotidase (Chróst 1991), are expected to be simultaneously active, P limitation becomes even less probable.

\section{Nitrogen budget}

A nitrogen budget was elaborated in a similar manner as the phosphorus budget. Assuming a C:N ratio of 5.0 (wt:wt) for the bacterioplankton (Fagerbakke et al. 1996), and the conventional Redfield ratio of 5.7 (wt:wt) for the phytoplankton, the nitrogen demand of both compartments was calculated. Values ranged from 10 and $7 \mathrm{mg} \mathrm{N} \mathrm{m}^{-2} \mathrm{~d}^{-1}$ in February to 1100 and $750 \mathrm{mg} \mathrm{N} \mathrm{m}{ }^{-2} \mathrm{~d}^{-1}$ during the cyanobacterial bloom at Stns 1 and 2, respectively. Log-transformed data of phytoplanktonic $\mathrm{N}$ demand showed high negative correlations to the log-transformed pool of $\mathrm{NO}_{3}$ and $\mathrm{NH}_{4}$ (calculated on an aereal basis) at both stations ( $\mathrm{R}=$ -0.84 and -0.75 for Stns 1 and 2, respectively; $p<$ 0.001 ). Especially during the cyanobacterial bloom the daily phytoplanktonic $\mathrm{N}$ demand was much higher than the available $\mathrm{NO}_{3}$ and $\mathrm{NH}_{4}$ concentrations. However, both ions are known to cycle rapidly within the water column during the growth period and, thus, the low concentrations of the ions are not an indication for a possible limitation. $N$ fixation seemed unlikely, because of the low frequency of heterocysts observed (Dokulil \& Mayer 1996). Bacterial N demand (logtransformed) was not significantly correlated to the pool of $\mathrm{NO}_{3}$ and $\mathrm{NH}_{4}(\mathrm{p}>0.05)$, which may indicate the importance of amino acids for the bacterioplankton $\mathrm{N}$ 

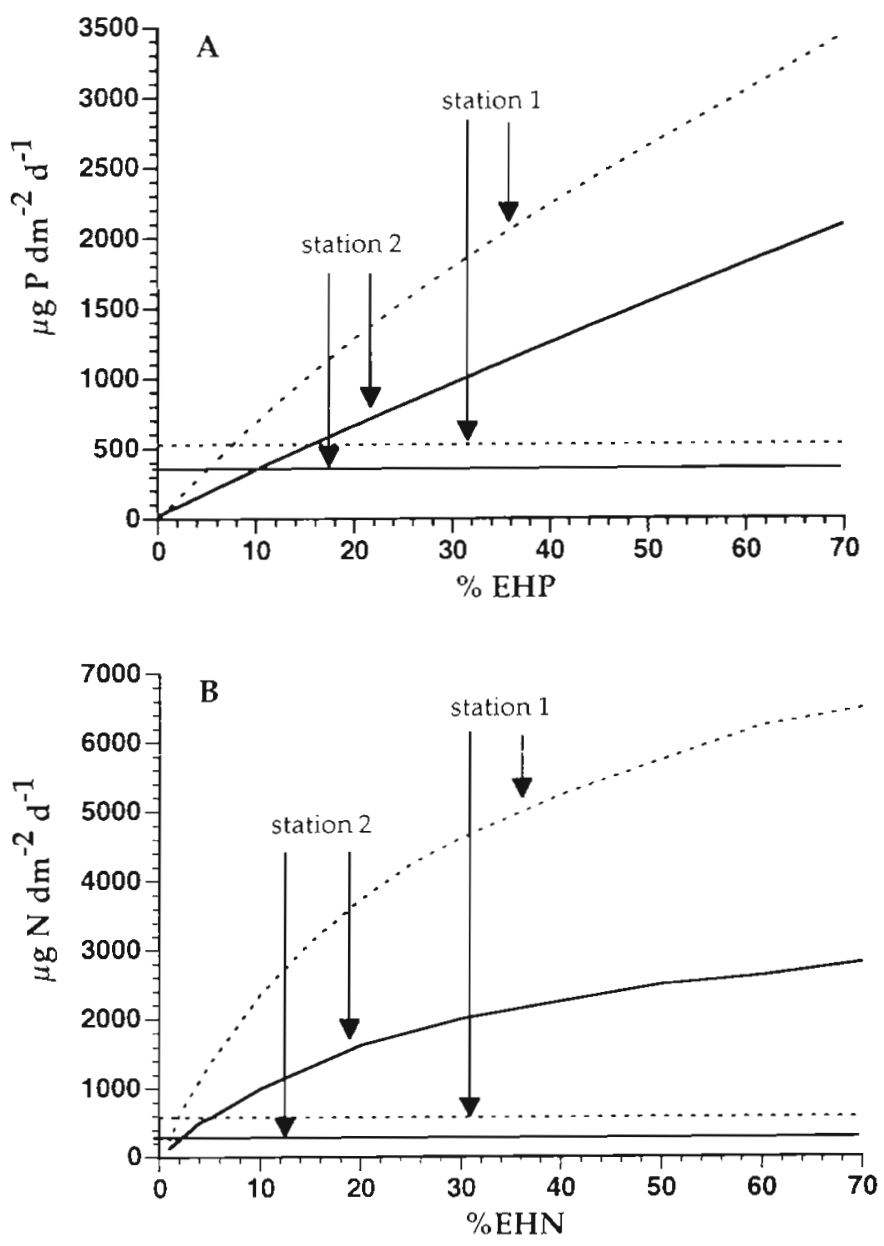

Fig. 7. (A) Annual mean rate of orthophosphate Iiberated by the activity of alkaline phosphatase ( $y$-axis) dependent on the percentage of dissolved organic phosphorus (DOP) assumed to be enzymatically hydrolyzable phosphorus (\% EHP; $x$ axis). Horizontal lines mark the annual mean phosphorus demand of both phytoplankton and bacterioplankton. Their intersection points with the calculated curves lobtained by applying increasing 2\% EHP steps in a Michaelis-Menten equation using the annual means of $V_{\max }$ and $K_{m}$ ) indicate the percentage of DOP present as EHP necessary to cover the $P$ demand of both groups by enzymatic activity alone. (B) Annual mean rate of nitrogen liberated by the activity of leuaminopeptidase ( $y$-axis) dependent on the percentage of dissolved organic nitrogen (DON) assumed to be enzymatically hydrolyzable nitrogen (\% EHN; $x$-axis). Horizontal lines mark the annual mean nitrogen demand of bacterioplankton. Their intersection points with the calculated curves (obtained by applying increasing $2 \%$ EHN steps in a Michaelis-Menten equation using the annual means of $V_{\max }$ and $K_{\operatorname{man}}$ ) indicate the percentage of DON present as EHN necessary to cover the $\mathrm{N}$

demand of bacterioplankton by enzymatic activity alone

demand. Because we have no information on whether the free dissolved amino acid composition in the water column reflects that of the bacterial proteins (Keil \& Kirchman 1993, Schweitzer \& Simon 1994), which is easily utilizable, we tried to estimate whether the activity of the leu-aminopeptidase in the Alte Donau could cover the nitrogen supply of bacterioplankton. As substrate pool for the AMP increasing percentages of the DON fraction were tested. DON was calculated by subtracting $\mathrm{NO}_{3}$ and $\mathrm{NH}_{4}$ from the soluble nitrogen $\left(N_{s}\right)$ pool. Nitrite could be neglected because of the low concentrations throughout the year (range: 1 to $35 \mu \mathrm{g}$ $\mathrm{N} \mathrm{l}^{-1}$; mean: $9 \mu \mathrm{g} \mathrm{N}^{-1}$ ). To convert the measured AMP activities, expressed as nmol amino acids $\mathrm{l}^{-1} \mathrm{~h}^{-1}$, into

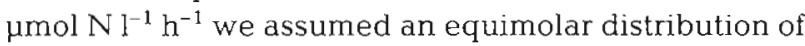
the 20 proteinogenic amino acids in the water column, thus leading to a conversion value of $1.45 \mu \mathrm{mol} \mathrm{N}$ $\mu \mathrm{mol}^{-1}$ amino acid. In Fig. $7 \mathrm{~B}$ the calculated annual mean rate of amino- $\mathrm{N}$ liberated by AMP activity is plotted against increasing concentrations of enzymatically hydrolyzable N (EHN) compounds, expressed as percentage of the DON fraction. The intersection points of the calculated curves with the annual mean $\mathrm{N}$ demand of the bacterioplankton show that at both stations less than $2 \%$ of DON in the form of EHN would have been sufficient in order for enzymatic activity alone to cover bacterial $\mathrm{N}$ demand. We have very little information on the percentage of the DCAA contribution to the total DON pool in the water column. Peptide- $\mathrm{N}$ was calculated to make up 20 to $30 \%$ of the total dissolved $\mathrm{N}$ in Lake Mendota (Wetzel 1983), leading to a peptide- $N$ contribution of some 40 to $60 \%$ to the DON, assuming that $50 \%$ of the total dissolved nitrogen is organic (Wetzel 1983). In Lake Constance about $8 \%$ of the DCAA fraction was shown to consist of labile compounds directly available for enzymatic degradation (Rosenstock 1996), but no information on the contribution of DCAA to the DON pool is available. Values in the same order of magnitude (1 to $10 \%)$ were found by Keil \& Kirchman (1993) in marine ecosystems. This would lead to calculated EHN values of some 0.4 to $6.0 \%$ of DON for aquatic systems in general. Considering that the hydrolysis of DCAA is not restricted to leuaminopeptidase, as the activities of other peptidase species are also contributing by chanelling DFAA into the DON pool, and that bacteria are also able to synthesize proteins de novo from glucose and ammonium (Simon \& Rosenstock 1992, Schweitzer \& Simon 1994), we tend to rule out $\mathrm{N}$ limitation for the bacterioplankton in the Alte Donar. However, this cannot be excluded for periods with low EHN and DFAA concentrations and/or high competition with phytoplankton for inorganic nutrients (e.g. beginning of an algal bloom).

\section{Carbon budget and ecosystem-level considerations}

In order to test our working hypothesis, namely that eutrophication and the subsequent shift in the equilib- 
Table 5. Comparison of phytoplanktonic primary production (PP), bacterial secondary production (BSP) and bacterial carbon demand $(B C D)$ at the 2 stations $(1,2)$ at the Alte Donau. $B C D$ was calculated assuming a bacterial carbon growth efficiency of $31 \%$ (Kristiansen et al. 1992)

\begin{tabular}{|c|c|c|c|c|c|c|c|c|c|c|}
\hline \multirow[t]{2}{*}{ Date } & $(\mu \mathrm{g} C$ & $\begin{array}{l}\text { Primary } \\
\left(\mathrm{m}^{-2} \mathrm{~h}^{-1}\right)\end{array}$ & $\begin{array}{l}\text { action } \\
\text { (mg C }\end{array}$ & $\left.m^{-2} d^{-1}\right)$ & \multicolumn{2}{|c|}{$\begin{array}{c}\text { BSP } \\
\left(m g C d \mathrm{~m}^{-2} \mathrm{~d}^{-1}\right)\end{array}$} & \multicolumn{2}{|c|}{$\begin{array}{c}\text { BCD } \\
\left(\mathrm{mg} \mathrm{C} \mathrm{dm}^{-2} \mathrm{~d}^{-1}\right)\end{array}$} & \multicolumn{2}{|c|}{ 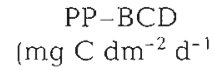 } \\
\hline & 1 & 2 & 1 & 2 & 1 & 2 & 1 & 2 & 1 & 2 \\
\hline 19 Арг 1994 & 466 & 180 & 5.8 & 2.2 & 2.0 & 0.7 & 6.5 & 2.2 & -0.7 & 0.0 \\
\hline 17 May 1994 & 1139 & 770 & 15.6 & 10.5 & 2.1 & 1.1 & 6.8 & 3.5 & 8.7 & 7.0 \\
\hline 31 May 1994 & 381 & 780 & 5.2 & 10.7 & 2.9 & 1.4 & 9.3 & 4.6 & -4.1 & 6.1 \\
\hline 13 Jun 1994 & 1033 & 510 & 14.9 & 7.4 & 2.9 & 0.3 & 9.3 & 1.1 & 5.7 & 6.3 \\
\hline 28 Jun 1994 & 1868 & 820 & 27.0 & 11.9 & 6.4 & 3.0 & 20.7 & 9.5 & 6.3 & 2.3 \\
\hline 13 Jul 1994 & 1998 & 1320 & 28.2 & 18.7 & 2.5 & 1.4 & 8.1 & 4.5 & 20.2 & 14.2 \\
\hline 25 Jul 1994 & 2084 & 800 & 29.4 & 11.3 & 6.7 & 4.1 & 21.7 & 13.3 & 7.8 & -2.0 \\
\hline 11 Aug 1994 & 3463 & 2690 & 44.7 & 34.8 & 4.1 & 1.2 & 13.3 & 3.7 & 31.4 & 31.0 \\
\hline 24 Aug 1994 & 4617 & 2290 & 59.7 & 29.6 & 2.4 & 1.2 & 7.7 & 3.9 & 51.9 & 25.6 \\
\hline 2 Sep 1994 & 2428 & 3620 & 27.6 & 41.1 & 2.6 & 1.3 & 8.4 & 4.2 & 19.2 & 36.9 \\
\hline 26 Sep 1994 & 1196 & 3560 & 13.6 & 40.4 & 3.1 & 0.7 & 9.9 & 2.3 & 3.7 & 38.1 \\
\hline 25 Oct 1994 & 133 & 210 & 1.3 & 2.1 & 3.3 & 0.9 & 10.5 & 2.8 & -9.2 & -0.7 \\
\hline 22 Nov 1994 & 1 & 4 & 0.01 & 0.03 & 2.1 & 1.4 & 6.8 & 4.5 & -6.8 & -4.5 \\
\hline $13 \mathrm{Dec} 1994$ & 1 & 4 & 0.01 & 0.03 & 2.2 & 0.8 & 7.1 & 2.6 & -7.1 & -2.6 \\
\hline 7 Feb 1995 & 1 & 4 & 0.01 & 0.03 & 0.5 & 0.3 & 1.5 & 1.0 & -1.5 & -1.0 \\
\hline 21 Feb 1995 & 1348 & 530 & 12.4 & 4.9 & 2.6 & 1.2 & 8.4 & 3.8 & 4.1 & 1.1 \\
\hline 7 Mar 1995 & 513 & 280 & 5.5 & 3.0 & 2.0 & 1.4 & 6.5 & 4.6 & -1.0 & -1.6 \\
\hline 23 Mar 1995 & 353 & 250 & 3.8 & 2.7 & 2.9 & 1.1 & 9.3 & 3.6 & -5.5 & -0.9 \\
\hline 4 Арг 1995 & 459 & 160 & 5.7 & 2.0 & 3.6 & 1.1 & 11.8 & 3.4 & -6.1 & -1.4 \\
\hline 19 Apr 1995 & 477 & 200 & 5.9 & 2.5 & 2.7 & 1.5 & 8.7 & 4.7 & -2.8 & -2.2 \\
\hline
\end{tabular}

rium of the Alte Donau led to an increase of the $\mathrm{C}$ flux into the detritus pool, we compared in a first step primary production to bacterial carbon demand (BCD) (Table 5). On a yearly basis (calculated from Table 5) planktonic primary production exceeded by far bacterial carbon demand with a remainder of about $140 \mathrm{~g} \mathrm{C}$ $\mathrm{m}^{-2} \mathrm{yr}^{-1}$ (Stn 1; $4 \mathrm{~m}$ depth) and $200 \mathrm{~g} \mathrm{C} \mathrm{m}^{-2} \mathrm{yr}^{-1}$ (Stn 2; $2 \mathrm{~m}$ depth), indicating the potential for accumulation of organic matter in the system. In addition, bacterioplankton can therefore be supposed not to be C limited during the major part of the year. Monthly balance calculations, however, indicated that negative values occurred at both stations during the period from October to April, when BCD was continuously higher than primary production, with the exception of February after the disappearance of the ice cover. From October to January ambient DOC concentrations, assumed to be derived from senescent and dying cyanobacterioplankton, could be considered to support bacterial growth, and temperature was most probably the limiting growth factor. At the beginning of February the lowest bacterial production values coincided with the lowest temperatures and an unfavourable $\mathrm{C}$ situation (low primary production and DOC values). Similar observations were made in Lake Constance during the winter months by Schweitzer \& Simon (1994). At the end of this month a slightly positive balance was possible due to a phytoplanktonic bloom after the release of ice-blocked organic and inorganic nutrients during the melting of the ice cover. From March to April BCD exceeded planktonic primary production, and again temperature and carbon as well as increasing bacterivory could be assumed to be the limiting factors for the bacterioplankton. During this period either the carbon left over from the short phytoplankton bloom in February or other $C$ sources must have been responsible for supporting bacterial growth. Additional carbon sources in the Alte Donau might be terrestrial runoff, leaf-fall and wind-borne material, whose system relevance is still to be determined. From May to October primary production was higher than BCD. At the beginning of June primary production exhibited a small decrease at both stations. At Stn 2 the decrease in primary production was also accompanied by a decrease in chl a values. An alteration of the phytoplanktonic community composition could be observed in July with filamentous cyanobacteria (Cylindrospermopsis raciborskii and Limnothrix redekei) gaining more importance and dominating the autotrophic planktonic compartment until October (Dokulil \& Mayer 1996). During this phase primary production exceeded by far the bacterial carbon demand (Table 5) and maybe viral lysis and predation were important in controlling bacterial growth during the summer months. An important portion of this cyanobacterial primary production is expected to remain ungrazed within the system. Experimental evidence shows that the presence of filamentous cyanobacteria, such as $C$. 
raciborskii, inhibits filtration rates of large cladocerans (Hawkins \& Lampert 1989) and that critical filament concentrations exist at which the growth rate of larger grazers is halted (Gliwicz 1990). This ungrazed portion of the primary production is therefore expected to enter the detritus pool and be available for bacterial degradation rather than entering the grazing food web in the water column.

In the macrophyte-dominated Kühwörter Wasser the bacterial compartment was shown to be insufficiently fueled by phytoplankton (Kirschner \& Velimirov 1997), indicating that macrophytes, benthic algae and import of terrestrial organic matter were subsidizing bacterioplanktonic secondary production during the major part of the year. Therefore, it was surprising that despite the big differences between both systems in the C flux from primary producers to bacterioplankton, the magnitude of the main bacterial features like cell numbers, cell volumes, biomass and secondary production was very similar in the mesotrophic macrophyte-dominated Kühwörter Wasser and the hypertrophic phytoplankton-dominated Alte Donau (Table 4). From this we conclude that irrespective of the source of organic matter, the quantity of the $\mathrm{C}$ flux through the bacterial compartment may not have changed after the shift of the Alte Donau from a macrophyte-dominated to a phytoplankton-dominated system. However, differences between the 2 systems were observed concerning the seasonal rhythm of morphotype composition (see above), bacterial numbers and secondary production. Maximal bacterial numbers in the Alte Donau were recorded in late autumn, at a time when a minimum was observed in the Kühwörter Wasser. In contrast, highest bacterial numbers in the Kühwörter Wasser occurred in early summer, followed by the BSP maximum in August, when aquatic macrophytes and chl a displayed their seasonal maximum. In the Alte Donau, on the other hand, the highest BSP values were registered in early summer and did not coincide with the summer phytoplankton bloom, which consisted mainly of filamentous cyanobacteria. Until now it remains unclear why the massive bloom of filamentous cyanobacteria did not lead to a bigger and more active bacterial population, although temperature conditions were optimal. We speculate that the cyanobacterial exudates might have consisted only to a small degree of readily utilizable organic matter and/or that inhibiting substances may have been excreted by Cylindrospermopsis raciborskii, a species which is known to be able to produce considerable amounts of toxic metabolites (Ohtani et al. 1992, Hawkins et al. 1997). Even though no analytical evidence of harmful concentrations in the Alte Donau is available, an effect on the microscale and thus the heterotrophic microbial compartment cannot be ruled out.
Acknowiedgements. This study was supported by a grant from the city of Vienna (MA 45; G. Ladinig). Our special thanks are due to J. Mayer, K. Donabaum, M. Schagerl and M. Dokulil for giving access to the information on chemical parameters from the water column as well as for providing the basis for valuable discussions on and insights into the investigated ecosystem. Special thanks also to $H$. Weilguni for his help with the statistical analyses and $H$. Güde (Institut für Seenforschung, Langenargen, Germany), M. Simon (Univ. Oldenburg, Germany) as well as 2 anonymous reviewers for valuable comments on an earlier version of the manuscript.

\section{LITERATURE CITED}

Amblard C, Carrias JF, Bourdier G, Maurin N (1995) The microbial loop in a humic lake: seasonal and vertical variations in the structure of the different communities. Hydrobiologia 300/301:71-84

Autio RM (1992) Temperature regulation of brackish water bacterioplankton. Ergebn Limnol 37:253-263

Bell RT, Ahlgren GM, Ahlgren I (1983) Estimating bacterioplankton production by measuring ${ }^{3} \mathrm{H}$-thymidine incorporation in a eutrophic swedish lake. Appl Environ Microbiol 45:1709-1721

Bernardi de R, Giussani G (1990) Are blue-green algae a suitable food for zooplankton? An overview. Hydrobiologia 200/201:29-41

Berninger UG, Wickham SA, Finlay BJ (1993) Trophic coupling within the microbial food web: a study with fine temporal resolution in a eutrophic freshwater ecosystem. Freshw Biol 30:419-432

Blindow I, Andersson G, Hargeby A, Johansson S (1993) Long-term pattern of alternative stable states in two shãllow eutrophic lakes. Freshw Biol 30:159-167

Boon PI (1991) Bacterial assemblages in rivers and billabongs of southeastern Australia. Microb Ecol 22:27-52

Chróst RJ (1989) Characterization and significance of $\beta$-glucosidase in lake water. Limnol Oceanogr 34:660-672

Chróst RJ (1991) Environmental control of the synthesis and activity of aquatic microbial ectoenzymes. In: Chróst RJ (ed) Microbial enzymes in the aquatic environment. Springer Verlag, New York, p 29-54

Chróst RJ, Overbeck J (1987) Kinetics of alkaline phosphatase activity and phosphorus availability for phytoplankton and bacterioplankton in Lake Plußsee. Microb Ecol 13: $229-248$

Chróst RJ, Overbeck J (1990) Substrate-ectoenzyme interaction: significance of $\beta$-glucosidase activity for glucose metabolism by aquatic bacteria. Arch Hydrobiol Beih Ergebn Limnol 34:93-98

Chróst RJ, Rai H (1993) Ectoenzyme activity and bacterial secondary production in nutrient-impoverished and nutrient-enriched freshwater mesocosms. Microb Ecol 25: $131-150$

Chróst RJ, Siuda W, Albrecht D, Overbeck J (1986) A method for determining enzymatically hydrolyzable phosphate (EHP) in natural waters. Limnol Oceanogr 31:662-667

Dokulil MT, Janauer GA (1995) Alternative stable states during eutrophication of a shallow urban lake in Vienna, Austria. Proceedings of the 6 th international conference on the conservation and management of lakes-Kasumigaura, 1995, p 730-733

Dokulil MT, Mayer J (1996) Population dynamics and photosynthetic rates of a Cylindrospermopsis-Limnothrix association in a highly eutrophic urban lake, Alte Donau, Vienna, Austria. Algol Stud 83:179-195 
Fagerbakke KM, Heldal M, Norland S (1996) Content of carbon, nitrogen, oxygen, sulfur and phosphorus in native aquatic and cultured bacteria. Aquat Microb Ecol 10:15-27

Francko DA (1984) Relationship between phosphorus functional classes and alkaline phosphatase activity in reservoir lakes. J Freshw Ecol 2:541-547

Gajewski AJ, Chróst RJ (1995) Production and enzymatic decomposition of organic matter by microplankton in an eutrophic lake. J Plankton Res 17:709-728

Gajewski AJ, Chróst RJ, Siuda W (1993) Bacterial lipolytic activity in an eutrophic lake. Arch Hydrobiol 128:107-126

Gajewski AJ, Kirschner AKT, Velimirov B (1997) Bacterial lipolytic activity in a hypertrophic dead arm of the river Danube in Vienna. Hydrobiologia 344:1-10

Gliwicz ZM (1990) Daphnia growth at different concentrations of blue-green filaments. Arch Hydrobiol 120:51-65

Gliwicz ZM, Lampert W (1990) Food thresholds in Daphnia species in the absence and presence of blue-green filaments. Ecology 7:691-702

Gliwicz ZM, Pijanowska J (1989) The role of predation in zooplankton succession. In: Sommer U (ed) Plankton ecology, succession in plankton communities. Springer Verlag, Berlin, p 253-297

Güde H (1989) The role of grazing on bacteria in plankton succession. In: Sommer U (ed) Plankton ecology, succession in plankton communities. Springer Verlag, Berlin, p 337-364

Haney JF, Forsyth DJ, James MR (1994) Inhibition of zooplankton filtering rates by dissolved inhibitors produced by naturally occurring cyanobacteria. Arch Hydrobiol 132: $1-13$

Hanson MA, Butler MG (1990) Early responses of plankton and turbidity to biomanipulation in a shallow prairie lake. Hydrobiologia 200/201:317-329

Hawkins P, Lampert W (1989) The effect of Daphnia body size on filtering rate inhibition in the presence of a filamentous cyanobacteria. Limnol Oceanogr 34:1084-1089

Hawkins PR, Chandrasena MR, Jones GJ, Humpage AR, Falconer IR (1997) Isolation and toxicity of Cylindrospermopsis raciborskii from an ornamental lake. Toxicon 35 : $914-919$

Hobbie JE, Daley RJ, Jasper S (1977) Use of Nuclepore filters for counting bacteria by epifluorescence microscopy. Appl Environ Microbiol 33:1225-1228

Hoppe HG (1983) Significance of exoenzymatic activities in the ecology of brackish water: measurements by means of methylumbelliferyl substrates. Mar Ecol Prog Ser 11: $299-308$

Hosper SH (1989) Biomanipulation, new perspectives for restoration of shallow, eutrophic lakes in the Netherlands. Hydrobiol Bull 23:5-10

Irvine K, Moss B, Balls H (1989) The loss of submerged plants with eutrophication. 2. Relationships between fish and zooplankton in a set of experimental ponds and conclusions. Freshw Biol 22:89-107

Jeppesen $E$, Jensen JP, Kristensen $P$, Søndergaard $M$, Mortensen E, Sortkjaer O, Olrik K (1990) Fish manipulation as a lake restoration tool in shallow, eutrophic, temperate lakes. 2: Threshold levels, longterm stability and conclusions. Hydrobiologia 200/201:219-227

Jürgens K, Güde H (1994) The potential importance of grazing-resistant bacteria in planktonic systems. Mar Ecol Prog Ser 112:169-188

Jürgens K, Stolpe G (1995) Seasonal dynamics of crustacean zooplankton, heterotrophic nanoflagellates and bacteria in a shallow, eutrophic lake. Freshw Biol 33:27-38

Keil RG, Kirchman DL (1993) Dissolved combined amino- acids: chemical form and utilization by marine bacteria Limnol Oceanogr 38:1256-1270

Kirschner AKT, Velimirov B (1997) Seasonal study of bacterial community succession in a temperate backwater system indicated by variation in morphotype numbers, biomass and secondary production. Microb Ecol 34:27-38

Kristiansen K, Nielsen H, Riemann B, Fuhrman JA (1992) Growth efficiencies of freshwater bacterioplankton. Microb Ecol 24:145-160

Leatherbarrow RJ (1987) Enzfitter. A non-linear regression data analysis program for the IBM PC. Elsevier-Biosoft, Cambridge

Legler C (1988) Ausgewählte Methoden der Wasseruntersuchung, Band 1: chemische, physikalisch-chemische und physikalische Methoden. VEB Gustav Fischer Verlag, Jena

Levontin RC (1969) The meaning of stability. In: National Bureau of Standards, US Department of Commerce, Brookhaven (ed) Diversity and stability in ecological systems. Symp Biol 22:13-24

Mathias CB, Kirschner AKT, Velimirov B (1995) Seasonal variations of virus abundance and viral control of the bacterial production in a backwater system of the Danube River. Appl Environ Microbiol 61:3734-3740

May RM (1973) Stability and complexity in model ecosystems Princeton University Press, Princeton, NJ

May RM (1977) Thresholds and breakpoints in ecosystems with a multiplicity of stable states. Nature 269:471--477

May RM (1981) Models for two interacting populations. In: May RM (ed) Theoretical ecology. Blackwell, Oxford, p 78-105

Mayer J, Dokulil MT, Salbrechter M, Berger M, Posch T, Pfister G, Kirschner AKT, Velimirov B, Steitz A, Ulbricht I (1997) Seasonal successions and trophic relations between phytoplankton, zooplankton, ciliates and bacteria in a hypertrophic shallow lake in Vienna, Austria. Hydrobiologia 342/343:165-174

Middelboe M, Søndergaard M, Letarte Y, Borch NH (1995) Attached and free-living bacteria: production and polymer hydrolysis during a diatom bloom. Microb Ecol 29:231-248

Moriarty DJ, Bell RT (1993) Bacterial growth and starvation in aquatic environments. In: Kjelleberg $S$ (ed) Starvation in bacteria. Plenum Press, New York, p 25-53

Moss B (1990) Engineering and biological approaches to the restauration from eutrophication in shallow lakes in which aquatic plant communities are important components. Hydrobiologia 200/201:367-377

Münster U, Chróst RJ (1990) Origin, composition and microbial utilization of DOM. In: Overbeck J, Chróst RJ (eds) Aquatic microbial ecology: biochemical and molecular approaches. Springer Verlag, New York, p 8-46

Norland S (1993) The relatioship between biomass and volume of bacteria. In: Kemp PF, Sherr EB, Sherr EB, Cole JJ (eds) Current methods in aquatic microbial ecology. Lewis Publ, Boca Raton, p 303-307

Nusch EA (1980) Comparison of different methods for chlorophyll and phaeopigment determination. Arch Hydrobiol Beih Ergebn Limnol 14:14-36

Nyström $T$ (1993) Global system approach to the physiology of the starved cell. In: Kjelleberg S (ed) Starvation in bacteria. Plenum Press, New York, p 25-53

Ohtani I, Moore RE, Runnegar MTC (1992) Cylindrospermopsin: a potent hepatotoxin from the blue green alga Cylindrospermopsis raciborskii. J Am Chem Soc 114: $7942-7944$

Pace ML, Cole JJ (1994) Comparative and experimental approaches to top-down and bottom-up regulation of bacteria. Microb Ecol 28:181-193 
Parsons TR, Maita Y, Lalli CM (1984) A manual of chemical and biological methods for seawater analysis. Pergamon Press, Oxford

Pedrós-Alió C, Brock TD (1982) Assessing biomass and production of bacteria in eutrophic Lake Mendota, Wisconsin. Appl Environ Microbiol 44:203-218

Pucsko R (1985) Phosphorverbindungen im Sediment des Piburger Sees. PhD thesis, Univ. Innsbruck

Riemann B, Jensen LM (1991) Measurement of phytoplankton primary production by means of the acidification and bubbling method. J Plankton Res 13:853-862

Rosenstock B (1996) Bakterielle Nutzung von gelösten Aminosauren und Proteinen und deren Freisetzung durch Plankton im Bodensee. Konstanzer Dissertationen, Band 527. Hartung Gorre Verlag, Konstanz

Scheffer M (1990) Multiplicity of stable states in freshwater systems. Hydrobiologia 200/201:475-486

Scheffer $M$, Hosper SH, Meijer ML, Moss B, Jeppesen E (1993) Alternative equilibria in shallow lakes. TREE 8 $275-278$

Schiemer F (1995) Revitalisierungsmaßnahmen für Augewässer-Möglichkeiten und Grenzen. Arch Hydrobiol Suppl 101:383-398

Schweitzer B, Simon M (1994) Growth limitation of planktonic bacteria in a large mesotrophic lake. Microb Ecol 28 $89-102$

Sime-Ngando T, Bourdier $G$, Amblard C, Pinel-Alloul B (1991) Short-term variations in specific biovolumes of different bacterial forms in aquatic ecosystems. Microb Ecol $21: 211-226$

Simon M, Azam F (1989) Protein content and protein synthesis rates of planktonic marine bacteria. Mar Ecol Prog Ser 51:201-213

Simon M. Rosenstock B (1992) Carbon and nitrogen sources of planktonic bacteria in Lake Constance studied by the composition and isotope dilution of intracellular amino acids. Limnol Oceanogr 37:1496-1511

Editorial responsibility: David Karl,

Honolulu, Hawaii, USA
Siuda W, Chróst RJ (1987) The relationship between alkaline phosphatase (APA) activity and phosphate availability for phytoplankton and bacteria in eutrophic lakes. Acta Microbiol Polonica 36:247-257

Somville M, Billen G (1983) A method for determining exoproteolytic activity in natural waters. Limnol Oceanogr 28 : $190-193$

Sondergaard M, Hansen B, Markager S (1995) Dynamics of dissolved organic carbon lability in a eutrophic lake. Limnol Oceanogr 40:46-54

Stevenson HL (1978) A case for bacterial dormancy in aquatic systems. Microb Ecol 4:127-133

Strickland JD, Parsons TR (1968) A practical handbook of seawater analysis. Bull Fish Res Board Can 167

Vadstein O, Olsen Y (1989) Chemical composition and phosphate uptake kinetics of limnetic bacterial communities cultured in chemostates under phosphorus limitation. Limnol Oceanogr 34:939-946

Vadstein O, Harkjerr BO, Jensen A, Olsen Y, Reinertsen $H$ (1989) Cycling of organic carbon in the photic zone of a eutrophic lake with special reference to the heterotrophic bacteria. Limnol Oceanogr 34:840-855

Vadstein O, Olsen Y, Reinertsen H (1993) The role of planktonic bacteria in phosphorus cycling in lakes - sink and link. Limnol Oceanogr 38:1539-1544

Velimirov B, Walenta-Simon M (1992) Seasonal changes in specific growth rates, production and biomass of a bacterial community in the water column above a Mediterranean seagrass system. Mar Ecol Prog Ser 80:237-248

Vollenweider RA (1974) Primary production in aquatic environments. IBP handbook no. 12, 2nd edn. Blackwell Sci., Oxford

Wetzel RG (1983) Limnology, 2nd edn. Sounders College publishing, Philadelphia

Wikner J, Hagstrom $\AA$ (1991) Annual study of bacterioplankton community dynamics. Limnol Oceanogr 36: $1313-1324$

Submitted: June 30, 1998; Accepted: September 29, 1998

Proofs received from author(s): June 10, 1999 